OPEN ACCESS

Edited by:

Sylvia Anton,

Institut National de la Recherche

Agronomique (INRA), France

Reviewed by:

Jose Eduardo Serrão,

Universidade Federal de Viçosa, Brazi

Samar Ramzi,

Agricultural Research, Education and Extension Organization (AREEO),

Iran

*Correspondence:

Sengottayan Senthil-Nathan senthil@msuniv.ac.in; senthilkalaidr@hotmail.com

Specialty section:

This article was submitted to

Invertebrate Physiology,

a section of the journa

Frontiers in Physiology

Received: 20 May 2019 Accepted: 19 December 2019

Published: 25 February 2020

Citation:

Senthil-Nathan S (2020) A Review of Resistance Mechanisms

of Synthetic Insecticides and Botanicals, Phytochemicals, and Essential Oils as Alternative Larvicidal Agents Against Mosquitoes.

Front. Physiol. 10:1591.

doi: 10.3389/fphys.2019.01591

\section{A Review of Resistance Mechanisms of Synthetic Insecticides and Botanicals, Phytochemicals, and Essential Oils as Alternative Larvicidal Agents Against Mosquitoes}

\author{
Sengottayan Senthil-Nathan*
}

Division of Biopesticides and Environmental Toxicology, Sri Paramakalyani Centre for Excellence in Environmental Sciences, Manonmaniam Sundaranar University, Tirunelveli, India

Mosquitoes are a serious threat to the society, acting as vector to several dreadful diseases. Mosquito management programes profoundly depend on the routine of chemical insecticides that subsequently lead to the expansion of resistance midst the vectors, along with other problems such as environmental pollution, bio magnification, and adversely affecting the quality of public and animal health, worldwide. The worldwide risk of insect vector transmitted diseases, with their associated illness and mortality, emphasizes the need for effective mosquitocides. Hence there is an immediate necessity to develop new eco-friendly pesticides. As a result, numerous investigators have worked on the development of eco-friendly effective mosquitocidal compounds of plant origin. These products have a cumulative advantage of being cost-effective, environmentally benign, biodegradable, and safe to non-target organisms. This review aims at describing the current state of research on behavioral, physiological, and biochemical effects of plant derived compounds with larvicidal effects on mosquitoes. The mode of physiological and biochemical action of known compounds derived from various plant families as well as the potential of plant secondary metabolites, plant extracts, and also the essential oils (EO), as mosquitocidal agents are discussed. This review clearly indicates that the application of vegetal-based compounds as mosquito control proxies can serve as alternative biocontrol methods in mosquito management programes.

Keywords: biopesticide, vector, secondary metabolites, phytochemical, physiology, enzyme, toxicity

\section{INTRODUCTION}

Vector borne diseases account for more than seven million deaths annually (World Health Organization [WHO], 2017), among which mosquito borne diseases are the most threatening due to their wide spread occurrence, consequently featuring a higher frequency of disease transmission (Lounibos, 2002; Tyagi et al., 2015). Among different mosquito families, Culicidae is a large family 
(3,300 Service species-41 genera) comprising Toxorhynchitinae, Anophelinae (anophelines), and also Culicinae (culicines) subfamilies (Service, 1996; Senthil-Nathan et al., 2005b). Among the 31 genera, Anopheles, Culex, and Aedes are the most detrimental. Anopheles species, are carriers of major life-threatening diseases (malaria and filariasis-transmitting agents, such as Wuchereria bancrofti, Brugia malayi, and Brugia timori) and also of a few arboviruses (Kalaivani et al., 2012; Benelli et al., 2018; Thanigaivel et al., 2019; Vasantha-Srinivasan et al., 2019).

The discovery of DDT's insecticidal properties in late 1930s/beginning of 1940 s and the following progress of organochlorine invention and organophosphate insecticides concealed biological pesticide merchandise-research since the responses to mosquito regulation were supposed to have remained established (Shaalan et al., 2005; Senthil-Nathan et al., $2006 a, b)$. The ranges of many of the mosquito species were not limited and keep expanding, thereby up surging the rates of disease incidence. Until recently, the use of several of the earlier synthetic-insecticides, such as permethrin and malathion, along with other organophosphates in vector control programes has been partial. This is due to absence of unique-insecticides, expense of synthetic-insecticides, apprehension for ecological sustainability, damaging influence on human health, besides further non-target populations, their persistent nature, greater amount of "biological magnification" through ecosystem and also the development of insecticide resistance (Ghosh et al., 2012). The emergence of DDT resistance in Aedes species (Ae. tritaeniorhynchus and Ae. sollicitans) lead to numerous drawbacks in mosquito control programs (Brown, 1986). Several categories of Mosquitocides are being implemented in malaria control programs (BHC, organophosphorus, carbamate, and pyrethroid). The ability of mosquitoes to evade the insecticidal action of these synthetic compounds are attributed to the increase in the rate of synthesis of detoxifying enzymes such as monoxygenases (MFOs), glutathione-S-transferases (GST) and carboxyl-cholinesterase (CCE). MFOs are often associated with metabolic resistance to pyrethroids, such as permethrin, while GSTs are usually associated with organochloride resistance such as DDT. Resistance to pyrethroids, organophosphates and carbamates, such as bendiocarb are incurred by the magnification of CCE activity (Hemingway and Ranson, 2000). Added insecticides, benzylphenyl urea and the larvicide, Bacillus thuringiensis israelensis (Bti), have partial use against mosquitoes. Unpredicted natural or anthropogenic associated ecological variations that modify the original habitats severely affect the vector biology thereby positively influencing their existence and disease incidence, thus constraining the frame-work of mosquito control strategies.

\section{BIOLOGICAL MANAGEMENT OF MOSQUITOES}

Several phytochemicals from several plant families are identified with larvicidal activities against different mosquito species (Table 1). Plant extracts with their augmented phytochemical elements have a recognized potential as a substitute to conventional mosquito control agents (Sukumar et al., 1991; Tripathi et al., 2009; Tehri and Singh, 2015). The main strategy for mosquito control deals with the restriction of the vector population. As a promising biocontrol agent, the compounds from the plants of the family Meliaceae such as neem Azadirachta indica A. Juss (Senthil-Nathan et al., 2005b; Senthil-Nathan, 2013), Indian white cedar, Dysoxylum malabaricum Bedd. (Senthil-Nathan et al., 2006a), D. beddomei and chinaberry tree, Melia azedarach L. (Senthil-Nathan et al., 2006b) were effective against An. stephensi (Senthil-Nathan et al., 2008). "Secondary metabolites" from Eucalyptus tereticornis Sm. (forest redgum, Myrtaceae) exhibited effective mosquitocidal activities against An. stephensi as reported by Senthil-Nathan (2007). Also, the crude metabolic extracts of Acanthospermum hispidum leaves were active against $A n$. stephensi, Ae. Aegypti, as well as $C x$. quinquefasciatus as reported by Vivekanandhan et al. (2018a,b). A study conducted on testing the mosquitocidal activity of Justicia adhatoda L. (Acanthaceae) leaf extracts revealed the potential of natural larvicidal agent against Ae. Aegypti (Thanigaivel et al., 2012, 2017a,b).

Besides secondary metabolites, essential oils (EOs) from plants were also recorded with effective mosquitocidal potentials. The EOs from the plants of Lamiaceae and Zingiberaceae were proved with bioactivity against Ae. aegypti (Kalaivani et al., 2012). The fern Actiniopteris radiata was testified with novel mosquitocidal activity against larvae of Ae. aegypti and An. Stephensi (Kamaraj et al., 2018). The seed oil extract of Acacia nilotica possessed robust larvicidal action against major mosquito vectors (Vivekanandhan et al., 2018a). A remarkable biological activity of EOs against Dengue vectors has been extensively reviewed by Chellappandian et al. (2017, 2018, 2019). Plant volatile oils were also conveyed with mosquitocidal potentials. As studied by Vasantha-Srinivasan et al. (2018), the crude volatile oil (CVO) from Piper beetle leaves possessed significant larvicidal, ovipositional, and repellency effects against Ae. Aegypti.

Derivatives of plants are enriched with active molecules with exceptional mosquitocidal properties and can be advanced as low cost environmentally friendly bio-pesticides. Many botanical extracts along with their chief constituents showed effective insect metabolism inhibition or stimulation of digestive enzymes (Senthil-Nathan et al., 2009; Napoleão et al., 2012; SenthilNathan, 2013). Unlike synthetic chemicals, previous literature on plant compounds doesn't provide any indication for the emergence of resistance so far. This is most likely due to the blend of several bioactive compounds with different mechanisms of action and therefore it is difficult for mosquito vectors to develop resistance (Mulla and Su, 1999; Shaalan et al., 2005).

\section{IMPACT OF PHYTOCHEMICALS ON THE PHYSIOLOGY OF MOSQUITO LARVAE}

As in general, plant secondary metabolites are evolved as protection mechanism against herbivory. When these toxic substances are encountered by the mosquitoes, a relatively unambiguous response is triggered that has a non-specific influence on a wide range of molecular targets such as 
TABLE 1 | Phytochemicals identified from the specific plant families and their larvicidal activity on the mosquito species.

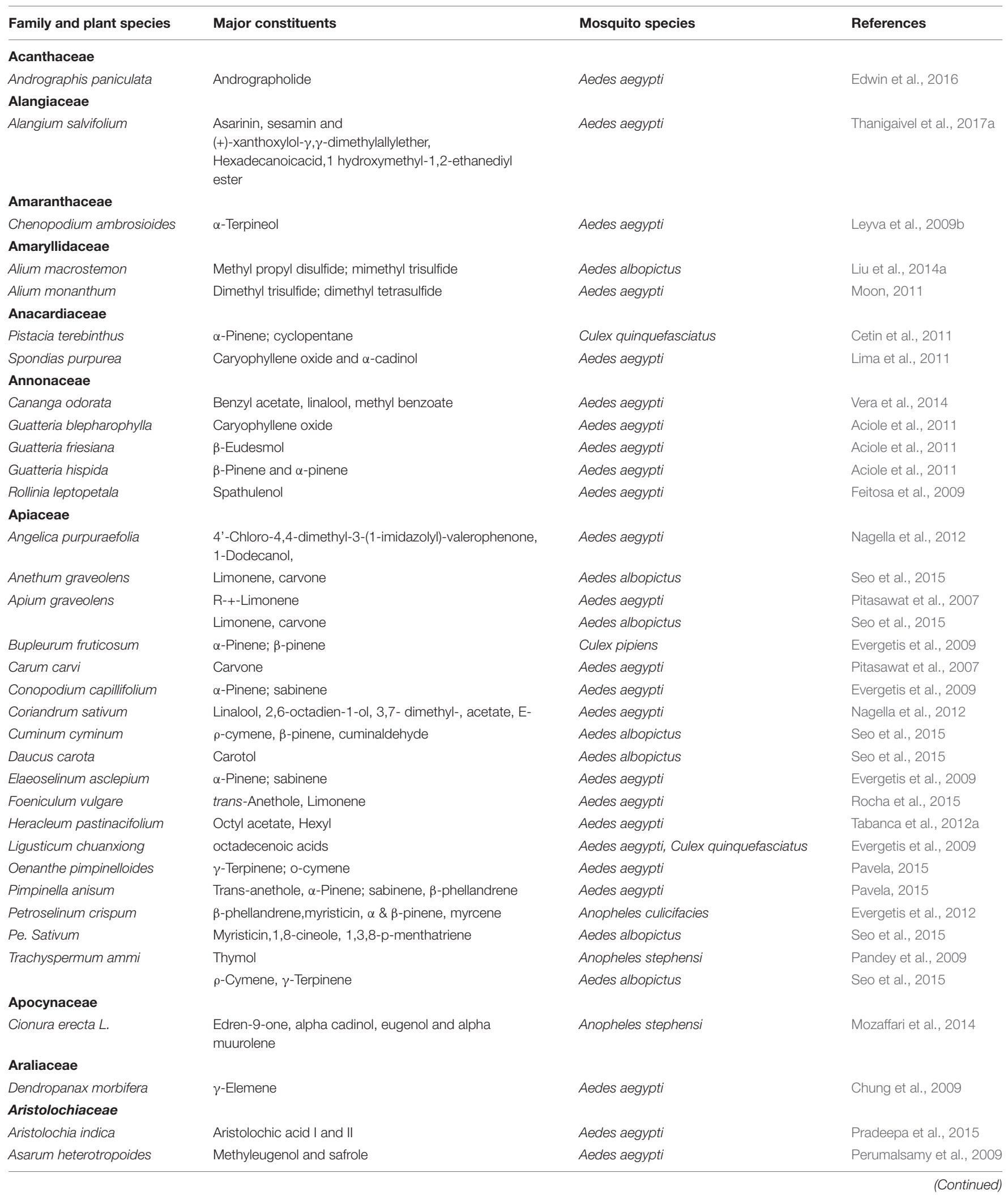


TABLE 1 | Continued

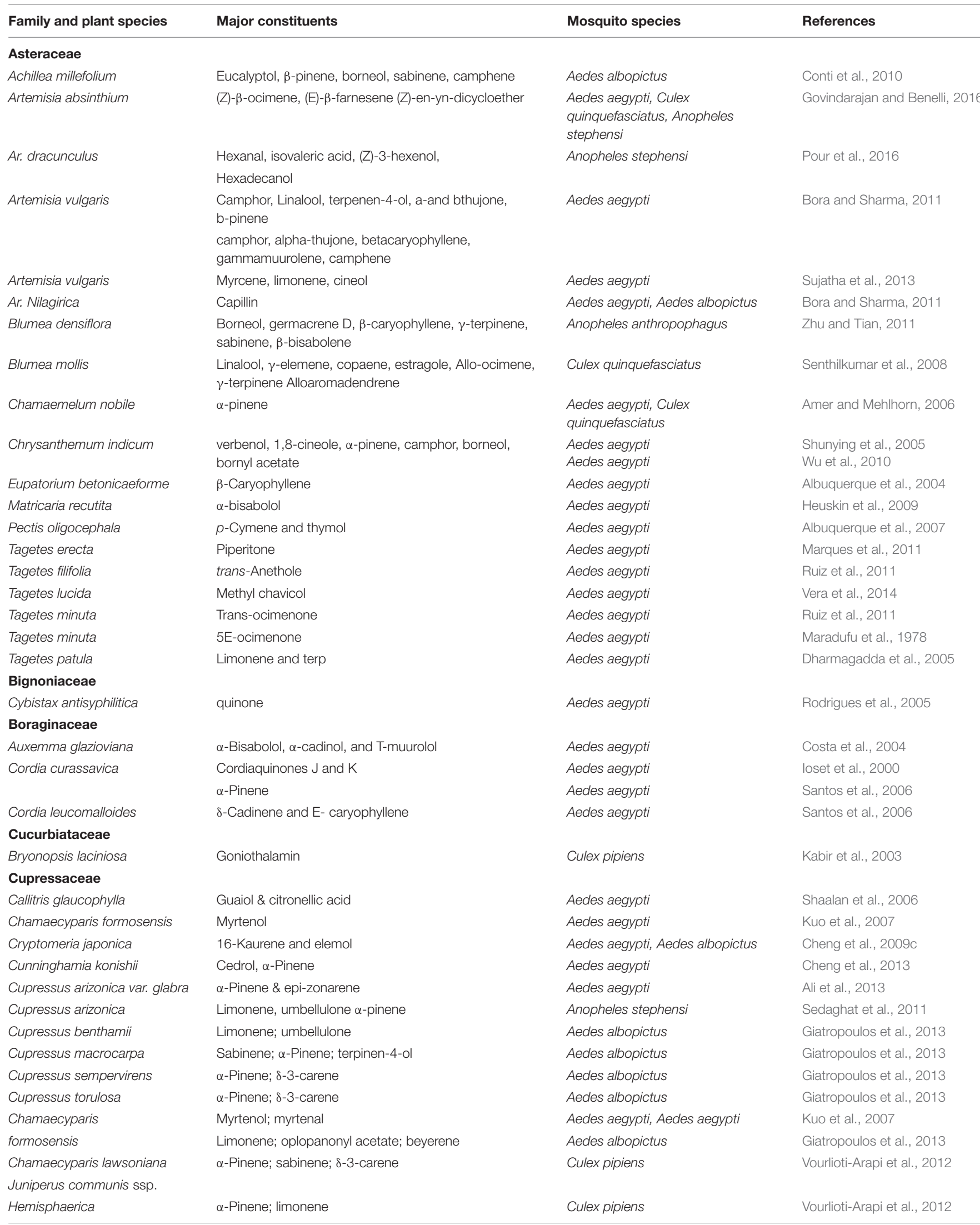


TABLE 1 | Continued

\begin{tabular}{|c|c|c|c|}
\hline Family and plant species & Major constituents & Mosquito species & References \\
\hline Juniperus foetidissima & Myrcene; germacrene-D; $\alpha$-Pinene & Culex pipiens & Vourlioti-Arapi et al., 2012 \\
\hline oxycedrus & $\alpha$-pinene & Culex pipiens & Vourlioti-Arapi et al., 2012 \\
\hline \multicolumn{4}{|l|}{ Juniperus oxycedrus $L$. } \\
\hline subsp. Macrocarpa & $\alpha$-Pinene; $\delta$-3-carene; $\beta$-phellandrene; $\alpha$-terpinyl acetate & Aedes albopictus & Giatropoulos et al., 2013 \\
\hline Tetraclinis articulate & $\alpha$-Pinene; bornyl acetate & Aedes albopictus & Giatropoulos et al., 2013 \\
\hline \multicolumn{4}{|l|}{ Dioncophyllaceae } \\
\hline Triphyophyllum peltatum & dioncophylline A & Anopheles stephensi & François et al., 1996 \\
\hline \multicolumn{4}{|l|}{ Euphorbiaceae } \\
\hline Croton nepetaefolius & Methyleugenol & Aedes aegypti & Morais et al., 2006 \\
\hline Croton regelianus & Ascaridole \& $p$-Cymene & Aedes aegypti & Torres et al., 2008 \\
\hline \multirow[t]{2}{*}{ Hymenaea courbaril } & $\alpha$-Copaene, spathulenol & Aedes aegypti & Aguiar et al., 2010 \\
\hline & Germacrene $D$ and $\beta$-caryophyllene & & \\
\hline Myroxylon pereirae & Benzyl benzoate & Aedes aegypti & Yenesew et al., 2003 \\
\hline Millettia dura & $\begin{array}{l}\text { Rotenoids, deguelin and tephrosin caryophyllene oxide; } \\
\text { phenol,4-3,7-dimethyl-3-ethenylocta-1,6-dienyl; } \\
\text { caryophyllene }\end{array}$ & Culex quinquefasciatus & Dua et al., 2013 \\
\hline Psoralea corylifolia & Citronellol & Aedes aegypti & Benelli et al., 2017 \\
\hline Geraniaceae & & Culex quinquefasciatus & Cavalcanti et al., 2004 \\
\hline Pelargonium graveolens & Neral; geranial & Culex quinquefasciatus & \\
\hline Gramineae & $\alpha$-Pinene & Aedes aegypti & Cetin et al., 2011 \\
\hline Cymbopogon citratus & Thymol & Culex pipiens & Govindarajan et al., 2013 \\
\hline \multirow[t]{2}{*}{ Lavandula gibsoni } & $\alpha$-Terpinolen and thymol & Aedes aegypti, Anopheles stephensi & Kulkarni et al., 2013 \\
\hline & & Culex quinquefasciatus. & \\
\hline Lavandula stoechas & Fenchone, 1,8-Cineole & Culex pipiens & Traboulsi et al., 2002 \\
\hline Lippia origanoides & Carvacrol & Aedes aegypti & Mar et al., 2018 \\
\hline Mentha Iongifolia & Piperitenone oxid & Aedes aegypti & Pavela et al., 2014 \\
\hline M. microcorphylla & Piperitenone, Pulegone, Piperitenone oxide & Culex pipiens & Traboulsi et al., 2002 \\
\hline M. spicata & Carvone & Aedes aegypti & Govindarajan et al., 2012 \\
\hline Nepeta cataria & E,Z-Nepetalactone and Z,E-nepetalactone & Aedes aegypti & Zhu et al., 2006 \\
\hline Ocimum americanum & E-Methyl-cinnamate & Aedes aegypti & Cavalcanti et al., 2004 \\
\hline Ocimum basilicum & Linalool; methyl eugenol & Aedes aegypti & Govindarajan et al., 2013 \\
\hline Ocimum gratissimum & Eugenol & Aedes aegypti & Cavalcanti et al., 2004 \\
\hline Ocimum sanctum & Methyleugenol & Culex pipiens & Gbolade and Lockwood, 2008 \\
\hline O. syriacum & Carvacrol, Thymol & Aedes aegypti & Traboulsi et al., 2002 \\
\hline Perilla frutescens & oleic, S-limonene, perillaldehyde & Aedes aegypti & Pohlit et al., 2011 \\
\hline Plectranthus amboinicus & Carvacrol & Aedes aegypti & Lima et al., 2011 \\
\hline Plectranthus mollis & Piperitone oxide, fenchone & Aedes aegypti & Kulkarni et al., 2013 \\
\hline Pogostemon cablin & $\begin{array}{l}\text { Patchouli alcohol, Seyshellene, } \alpha \text {-bulnesene, } \\
\text { Norpatchoulenol }\end{array}$ & Aedes aegypti & Lima-Santos et al., 2019 \\
\hline Pulegium vulgare & Pulegone; carvone & Aedes albopictus & Pavela, 2015 \\
\hline
\end{tabular}


TABLE 1 | Continued

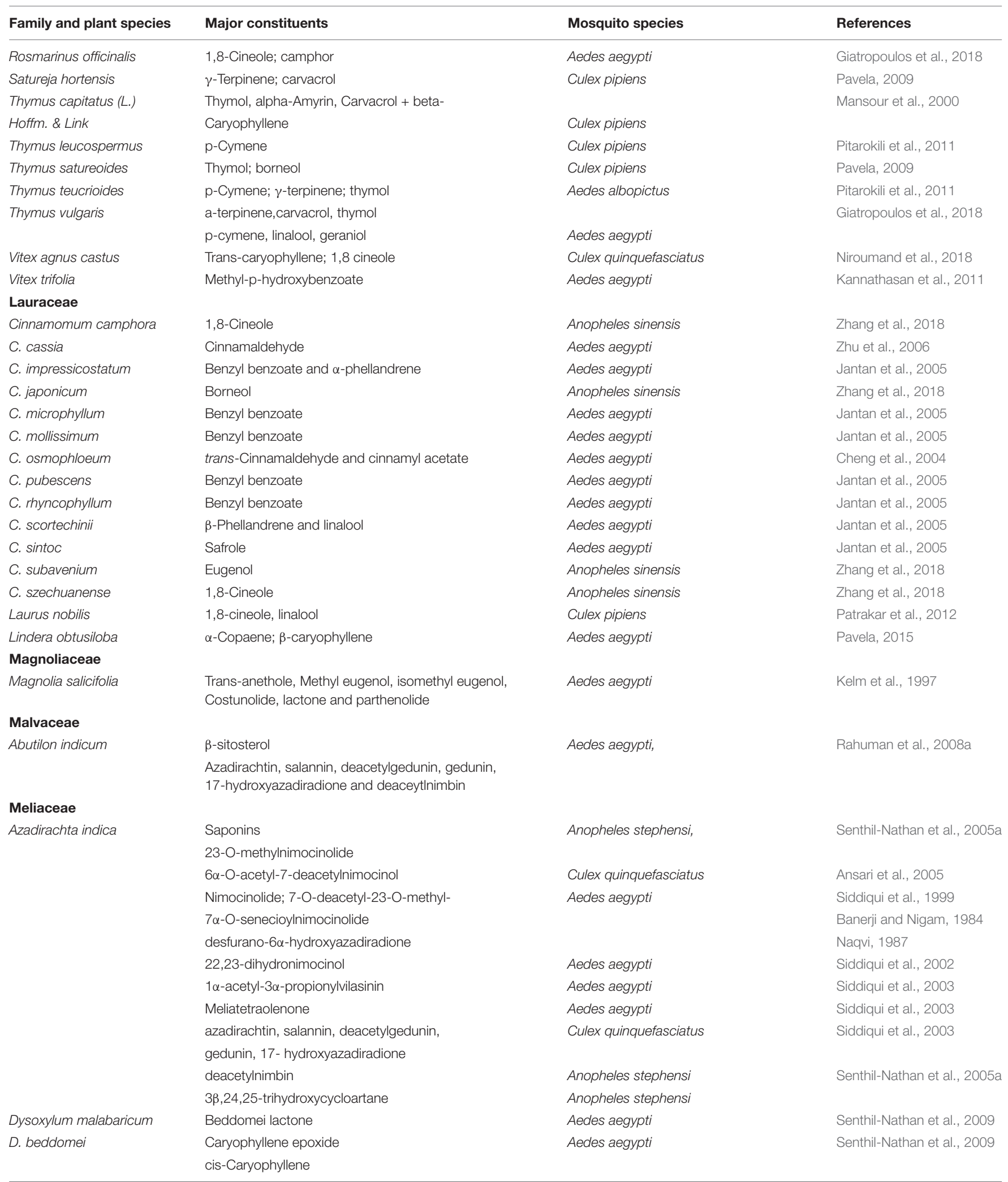


TABLE 1 | Continued

\begin{tabular}{|c|c|c|c|}
\hline Family and plant species & Major constituents & Mosquito species & References \\
\hline Guarea humaitensis & $1 \alpha, 7 \alpha, 11 \beta$-triacetoxy- $4 \alpha$-carbomethoxy- & Aedes aegypti & Magalhães et al., 2010 \\
\hline G. scabra & 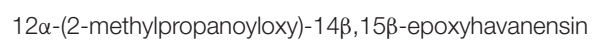 & Aedes aegypti & Magalhães et al., 2010 \\
\hline \multirow[t]{4}{*}{ Turraea floribunda } & $1 \alpha, 11 \beta$-diacetoxy- $4 \alpha$-carbomethoxy- $7 \alpha-$ & Aedes aegypti & Ndung'u et al., 2004 \\
\hline & 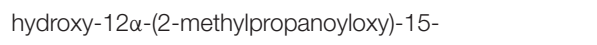 & Aedes aegypti & Ndung'u et al., 2004 \\
\hline & oxohavanensin; $1 \alpha$-acetyl-3 3 - & Culex pipiens & Ndung'u et al., 2004 \\
\hline & propionylvilasinin & Culex pipiens & Ndung'u et al., 2003 \\
\hline \multirow[t]{3}{*}{ Turraea wakefieldii } & $11 \beta, 12 \alpha$-diacetoxyneotecleanin & Culex pipiens & Ndung'u et al., 2003 \\
\hline & 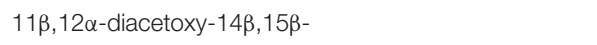 & Aedes aegypti & Ndung'u et al., 2003 \\
\hline & epoxyneotecleanin & Aedes aegypti & Ndung'u et al., 2003 \\
\hline \multicolumn{4}{|l|}{ Myrtaceae } \\
\hline Eucalyptus benthamii & $\alpha$-Pinene & Aedes aegypti & Lucia et al., 2012 \\
\hline E. botryoides & p-Cymene, $\alpha$-eudesmol, and 1,8-cineol & Aedes aegypti & Lucia et al., 2012 \\
\hline E. camaldulensis & 1,8-Cineol, p-cymene and $\beta$-phellandrene & Aedes aegypti & Lucia et al., 2008 \\
\hline \multirow[t]{2}{*}{ E. citriodora } & Citronellal; citronellol; & Aedes aegypti & Vera et al., 2014 \\
\hline & $\alpha$-humulene isopulegol & & \\
\hline E. dunnii & 1,8-Cineol and $\gamma$-terpinene & Aedes aegypti & Lucia et al., 2008 \\
\hline E. fastigata & p-Cymene & Aedes aegypti & Lucia et al., 2012 \\
\hline E. globulus & 1,8-Cineol & Aedes aegypti Anopheles arabiensis & Massebo et al., 2009 \\
\hline E. grandis & $\alpha$-Pinene & Aedes aegypti & Lucia et al., 2007 \\
\hline E. gunnii & 1,8-Cineol and p-cymene & Aedes aegypti & Lucia et al., 2008 \\
\hline E. nobilis & 1,8-Cineol & Aedes aegypti & Lucia et al., 2012 \\
\hline E. radiata & 1,8-Cineol & Aedes aegypti & Lucia et al., 2012 \\
\hline E. robusta & $\alpha$-Pinene & Aedes aegypti & Lucia et al., 2012 \\
\hline E. saligna & 1,8-Cineol and p-cymene & Aedes aegypti & Lucia et al., 2008 \\
\hline E. tereticornis & $\beta$-Phellandrene and 1,8-cineol & Aedes aegypti & Lucia et al., 2008 \\
\hline E. urophylla & 1,8-Cineol & Aedes aegypti & Cheng et al., 2009b \\
\hline E. melanadenia & 1,8-Cineol & Aedes aegypti & Aguilera et al., 2003 \\
\hline Myrtus communis & 1,8 Cineole, $\alpha$-Pinene, Linalool & Culex quinquefasciatus & Traboulsi et al., 2002 \\
\hline M. dissitiflora & Terpinen-4-ol & Aedes aegypti & Park et al., 2011 \\
\hline M. leucadendron & 1,8-Cineol, $\alpha$-pinene, and $\alpha$-terpineol & Aedes aegypti & Leyva et al., 2008 \\
\hline M. linariifolia & Terpinem-4-ol and $\gamma$-terpinene & Aedes aegypti & Park et al., 2011 \\
\hline M. quinquenervia & 1,8-Cineol and E-nerolidol & Aedes aegypti & Park et al., 2011 \\
\hline Pimenta dioica & Eugenol, linalool & Aedes aegypti & Pereira et al., 2014 \\
\hline P. racemosa & Terpinem-4-ol and 1,8-cineol & Aedes aegypti & Aciole, 2009 \\
\hline \multirow[t]{2}{*}{ P. guajava } & 1,8-Cineol and $\beta$-caryophyllene & Culex pipiens & Leyva et al., 2009a \\
\hline & 1,8-Cineol & Aedes aegypti & Lima et al., 2011 \\
\hline$P$. rotundatum & Eugenol & Aedes aegypti & Aguilera et al., 2003 \\
\hline Syzygium aromaticum & Eugenol & Aedes aegypti & Costa et al., 2005 \\
\hline \multicolumn{4}{|l|}{ Orchidaceae } \\
\hline Vanilla fragrans & $\begin{array}{l}\text { 4-ethoxymethylphenol, 4-butoxymethylphenol, vanillin, } \\
\text { 4-hydroxy-2-methoxycinnamaldehyde and } \\
\text { 3,4-dihydroxyphenylacetic acid }\end{array}$ & Culex pipiens & Sun et al., 2001 \\
\hline \multicolumn{4}{|l|}{ Pinaceae } \\
\hline Cupressus L., & limonene, $\alpha$ \& $\beta$-pinene, & Aedes aegypti & Burfield, 2000 \\
\hline Juniperus $L$. & 3-carene & Aedes aegypti & Burfield, 2000 \\
\hline Pinus brutia & $\alpha$-Pinene and $\beta$-pinene & Aedes albopictus & Koutsaviti et al., 2015 \\
\hline P. halepensis & $\beta$-Caryophyllene & Aedes albopictus & Koutsaviti et al., 2015 \\
\hline P. kesiya & $\alpha$-Pinene, $\beta$-pinene, myrcene and germacrene $D$. & $\begin{array}{l}\text { Aedes aegypti, Culex quinquefasciatus, } \\
\text { Anopheles stephensi }\end{array}$ & Govindarajan et al., 2016 \\
\hline P. longifolia & k-terpineol & $\begin{array}{l}\text { Culex quinquefasciatus, Anopheles } \\
\text { culicifacies }\end{array}$ & Ansari et al., 2005 \\
\hline P. stankewiczii & Germacrene $D \alpha$-Pinene and $\beta$-pinene & Aedes albopictus & Koutsaviti et al., 2015 \\
\hline P. sylvestris & $\begin{array}{l}\text { Eugenol 3, Cyclohexene-1-methanol, } \alpha-4- \\
\text { trimethyl }\end{array}$ & Aedes aegypti, Culex quinquefasciatus & Fayemiwo et al., 2014 \\
\hline
\end{tabular}


TABLE 1 | Continued

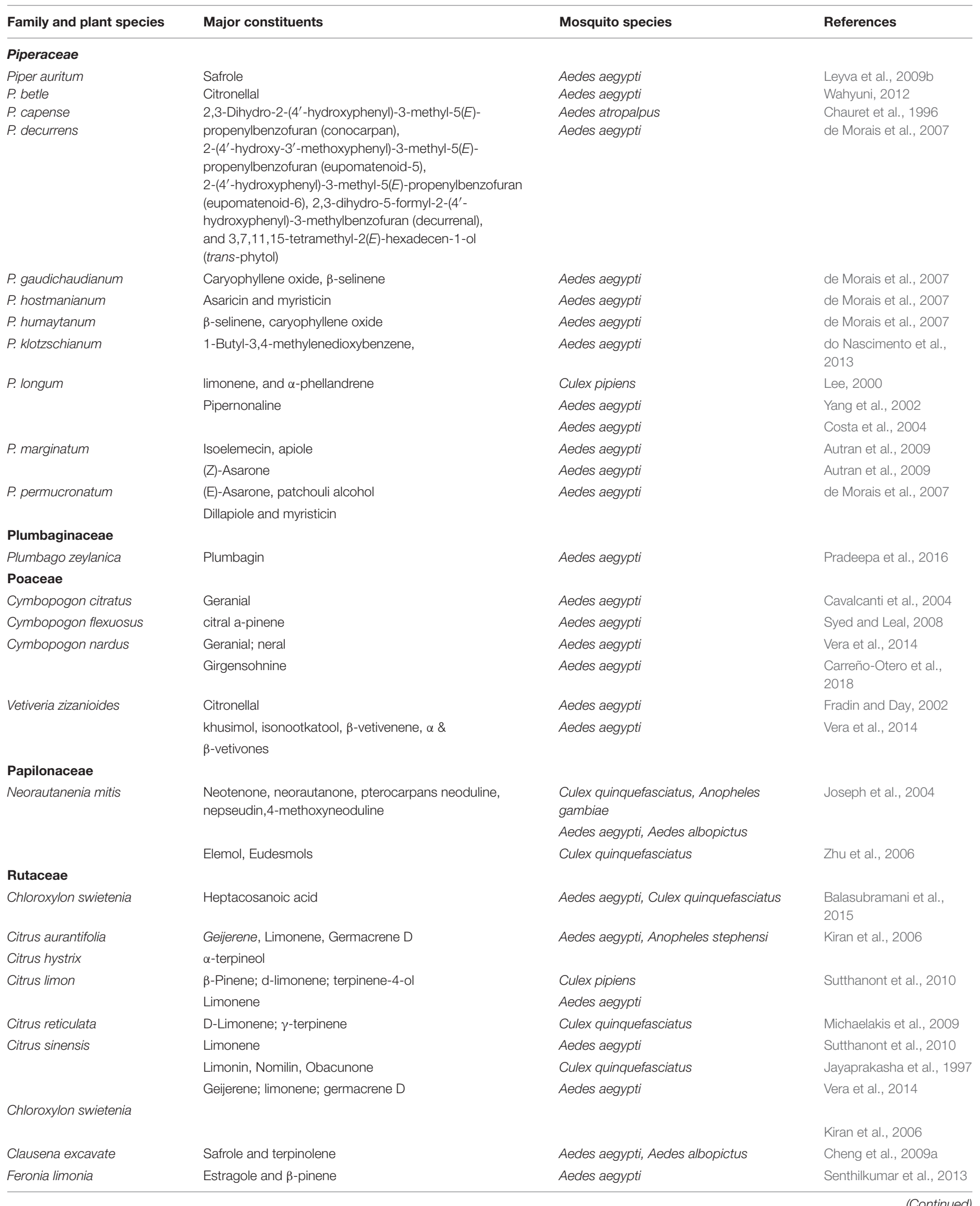


TABLE 1 | Continued

\begin{tabular}{|c|c|c|c|}
\hline Family and plant species & Major constituents & Mosquito species & References \\
\hline Ruta graveolens & Undecan-2-one & Aedes aegypti & Tabanca et al., 2012b \\
\hline Swinglea glutinosa & $\alpha$-Pinene & & \\
\hline Toddalia asiatica & Linalool & Aedes aegypti & Nyahanga et al., 2010 \\
\hline Zanthoxylum armatum & Linalool & Aedes aegypti & Tiwary et al., 2007 \\
\hline \multirow[t]{3}{*}{ Z. avicennae } & 1,8-Cineole & Aedes albopictus & Liu et al., 2014b \\
\hline & Limonene & Aedes aegypti & Pitasawat et al., 2007 \\
\hline & Methyl heptyl ketone & Aedes aegypti & Borah et al., 2012 \\
\hline Z. piperitum & $\begin{array}{l}\text { Asarinin, sesamin and } \\
(+) \text {-xanthoxylol- } \gamma, \gamma \text {-dimethylallylether }\end{array}$ & Aedes aegypti, Culex pipiens & Kim and Ahn, 2017 \\
\hline Santalum L. spp. & $\alpha$-santalol & Aedes aegypti, Culex pipiens & Jones et al., 2007 \\
\hline Santalum album & Guaiol, elemol, and eudesmol & Anopheles stephensi, & Amer and Mehlhorn, 2006 \\
\hline Schisandraceae & & Aedes aegypti & \\
\hline Illicium verum & Eugenol, $\alpha$-Terpinyl acetate, Eucalypt, ol, (E)-anethole & Culex quinquefasciatus & Kimbaris et al., 2012 \\
\hline \multicolumn{4}{|l|}{ Scrophulariaceae } \\
\hline Capraria biflora L. & $\alpha$-Humulene & Aedes aegypti & Souza et al., 2012 \\
\hline Stemodia maritima & $\beta$-Caryophyllene and caryophyllene oxide & Aedes aegypti & Arriaga et al., 2007 \\
\hline \multicolumn{4}{|l|}{ Tiliaceae } \\
\hline Microcos paniculata & $\begin{array}{l}\text { N-Methyl-6b-(deca-l', 3', 5'-trienyl)-3b-methoxy- } \\
\text { 2bmethylpiperidine }\end{array}$ & Aedes aegypti & Bandara et al., 2000 \\
\hline \multicolumn{4}{|l|}{ Verbenaceae } \\
\hline L. microphylla & 1,8-cineole, thymol, $\alpha$-pinene & Aedes aegypti & Santiago et al., 2006 \\
\hline L. nodiflora & Camphor, $p$-cymene, $\gamma$-terpinene & Aedes aegypti & Santiago et al., 2006 \\
\hline L. sidoides & Thymol & Aedes aegypti & Costa et al., 2005 \\
\hline \multicolumn{4}{|l|}{ Zingiberaceae } \\
\hline Alpinia purpurata & $\beta$-Caryophyllene and $\beta$-pinene & Aedes aegypti & Santos et al., 2012 \\
\hline \multirow[t]{2}{*}{ Curcuma aromatic } & $1 \mathrm{H}-3 \mathrm{a}, 7-$ Methanoazulene and curcumene & Aedes aegypti & Choochote et al., 2005 \\
\hline & Turmerone, curcumene, and zingiberene & & \\
\hline Curcuma longa & 1,8-Cineol and p-cymene & Aedes aegypti & Leyva et al., 2008 \\
\hline Curcuma zedoaria & Dodecanal & Aedes aegypti & Pitasawat et al., 2007 \\
\hline Hedychium coccineum & 1,8-Cineol and $\beta$-pinene & Aedes aegypti & Sakhanokho et al., 2013 \\
\hline Hedychium sp. & 1,8-Cineol & Aedes aegypti & Sakhanokho et al., 2013 \\
\hline Kaempferia galanga & Ethyl trans-p-methoxycinnamate & Aedes aegypti & Munda et al., 2018 \\
\hline Kaempferia galanga & Ethyl cinnamate & Aedes aegypti & Munda et al., 2018 \\
\hline Zingiber officinale & 4-Gingero & Aedes aegypti, Culex quinquefasciatus & Rahuman et al., 2008b \\
\hline Zingiber officinale & 6-Dehydrogingerdione & Aedes aegypti, Culex quinquefasciatus & Rahuman et al., 2008b \\
\hline Zingiber officinale & 6-Dihydrogingerdione & Aedes aegypti, Culex quinquefasciatus & Rahuman et al., 2008b \\
\hline Zingiber zerumbet & $\alpha$-Humulene; zerumbone & Aedes aegypti & Sutthanont et al., 2010 \\
\hline
\end{tabular}


proteins, nucleic-acids, bio-membranes, besides added cellular components. Consequently, the physiology is disrupted at numerous receptor sites, eventually causing an abnormality in the nervous system. Plant metabolites affect several vital physiological functions that include inhibition of "AChE" as well as "GABA-gated" chloride channel, disruption of $\mathrm{Na}-\mathrm{K}$ ion exchange besides constricting the cellular respiration. As a subsequent event, the alteration of these enzyme levels gives rise to several anomalies that include the obstruction of nerve cell membranes and octopamine receptors along with calcium channel blockage, resulting in hormonal imbalance, mitotic poisoning, and also modifications of the molecular basis of morphogenesis (Rattan, 2010).

Synthetic insecticides generally increase the level of detoxifying enzymes. Phytochemicals target the mentioned cellular mechanisms and potentially disturb their functions (Figure 1; Zibaee and Bandani, 2010; Zibaee, 2011; Kaur et al., 2014; Senthil-Nathan, 2015). Physiological effects of phytochemicals are discussed below.

\section{IMPACT OF PHYTOCHEMICALS ON DETOXIFYING ENZYMES}

The antioxidant and detoxification enzymes of mosquito vectors are vital in detoxification of reactive oxygen species (ROS) synthesized by the toxic chemicals (Rattan, 2010). Esterase and phosphatase of the mosquito vectors plays a key role in several physiological events (Koodalingam et al., 2014). Excessive usage of toxic chemicals on mosquito control caused insecticide resistance through sodium channel mutations, activation of detoxification enzymes, and upregulation of key genes and other regulatory components like MicroRNAs (miRNAs). The CYP450s, GSTs, SOD, and esterase gene families are recognized as the foremost four enzymes accountable for the metabolicresistance of the insects (Hemingway et al., 2004). Generally, detoxifying enzymes are involved in digestion, reproduction, juvenile hormone metabolism, neuronal conduction, moulting, and more importantly detoxification of toxic chemicals (Koodalingam et al., 2014). Phosphatases are involved in tissue development, cellular differentiation, carbohydrate metabolisms, and synthesis of ATP (Koodalingam et al., 2014). Mainly these two major classes of detoxifying enzymes are considered for evaluating the impact of toxic chemicals on physiological or biochemical events of arthropod vectors.

Carboxyl-esterases (EC3.1.1.1) are non-specific omnipresent enzymes that are associated to the major "endogenous" functions in insects, which hydrolyze a different carboxylic-acid ester (Lija-Escaline et al., 2015). Generally, the metabolic pathway of these enzymes was targeted by the chemical pesticides, especially the fourth generation class of Pyrethroids, which acts on the voltage sensitive sodium channels and blocks the mosquito nervous system (Hong et al., 2014). Esterases can also target by sequestering the insecticide through rapid binding and slowly releasing the insecticide metabolites (Karunaratne et al., 1993). This latter type of resistance requires the presence of increased quantities of esterase due to the 1:1 stoichiometry of the reaction and decreases the metabolic breakdown time.

Plant extracts and their derivatives have been widely reported to decrease the levels of carboxylesterase ( $\alpha$ - $\beta$-carboxylesterase) level in the Ae. aegypti larva (Koodalingam et al., 2014; LijaEscaline et al., 2015). Besides exhibiting larvicidal activity Alangium salvifolium, also substantially reduced the levels of $\alpha$, $\beta$-carboxylesterase as well as superoxide dismutase (SOD) in Ae. Aegypti (Thanigaivel et al., 2017a). Myrrh commiphora molmol (oil and oleo-resin extract) instigated biochemical changes in $C x$. pipiens that affected the cell proteins, as well as loss of enzyme activity (Massoud et al., 2001).

Higher rates of enzyme activities, such as SOD (Agra-Neto et al., 2014; Lija-Escaline et al., 2015) and physiological enzymes like esterase (Wheelock et al., 2005; Lija-Escaline et al., 2015), phosphatases (Walter and Schütt, 1974; Urich, 1994) are recorded with increasing developmental stages and these are considered responsible for increased pyrethroid resistance. The Mosquito vectors that established resistance to Temephos have been found to possess genes that insensitized ACHE on exposure to pesticides. Insects were also characterized by the over expression of varied forms of detoxifying enzymes (GST, SOD, and esterases) (Larson et al., 2010).

Glutathione-S-transferases are a class of detoxification enzymes considered to play a vital role in the existence of insects exposed to toxic metabolites. Increased GST activities are connected with the expression of metabolic resistance toward insecticides (Clark, 1990). GSTs can break down a broad range of substances; amplified GST activity is possibly as a response to an environmental stress. Generally, Cytochrome P450s (CYP450) displayed upregulation when induced by plant secondary metabolites in diverse insect pests especially against the vectors of human diseases (Caballero et al., 2008) and have members which are considered as major elements conferring resistance against insecticides (i.e., CYP2, CYP4, and CYP6) (Sun et al., 2001). The upregulation of GST enzymes usually at the exposure of a prominent dosage of plant compounds suggests the activity of a major detoxification process (Edwin et al., 2016). Consequently, the levels of GST expression may be used as a biomarker to detect the development of resistance (Jukic et al., 2007).

CYP450 group of enzyme family are also designated as key indicators of metabolic resistance besides susceptibility to insecticides (David et al., 2013). Many previous research outcomes proved alteration or inhibition in the expression of major detoxifying enzymes exposed to plant chemicals. Thanigaivel et al. (2017a) showed increase in the rate of GST activity in IV instar larvae of dengue mosquito exposed to methanolic leaf extract of $J$. adhatoda with their major derivative 3-hydroxy-2,3-dihydropyrrolo[2,1-b]quinazolin-9(1h) one $(26.37 \%)$. Likewise, carboxylesterase activities differed significantly in Ae. aegypti post treatment with the leaf extracts of $P$. nigrum with their major derivatives thymol (20.77\%) (Lija-Escaline et al., 2015). Correspondingly, the activity of major enzymes (esterases, GST, and CYP450) of dengue mosquito severely affected post treated with dynamic plant compound andrographolide derived from Andrographis 

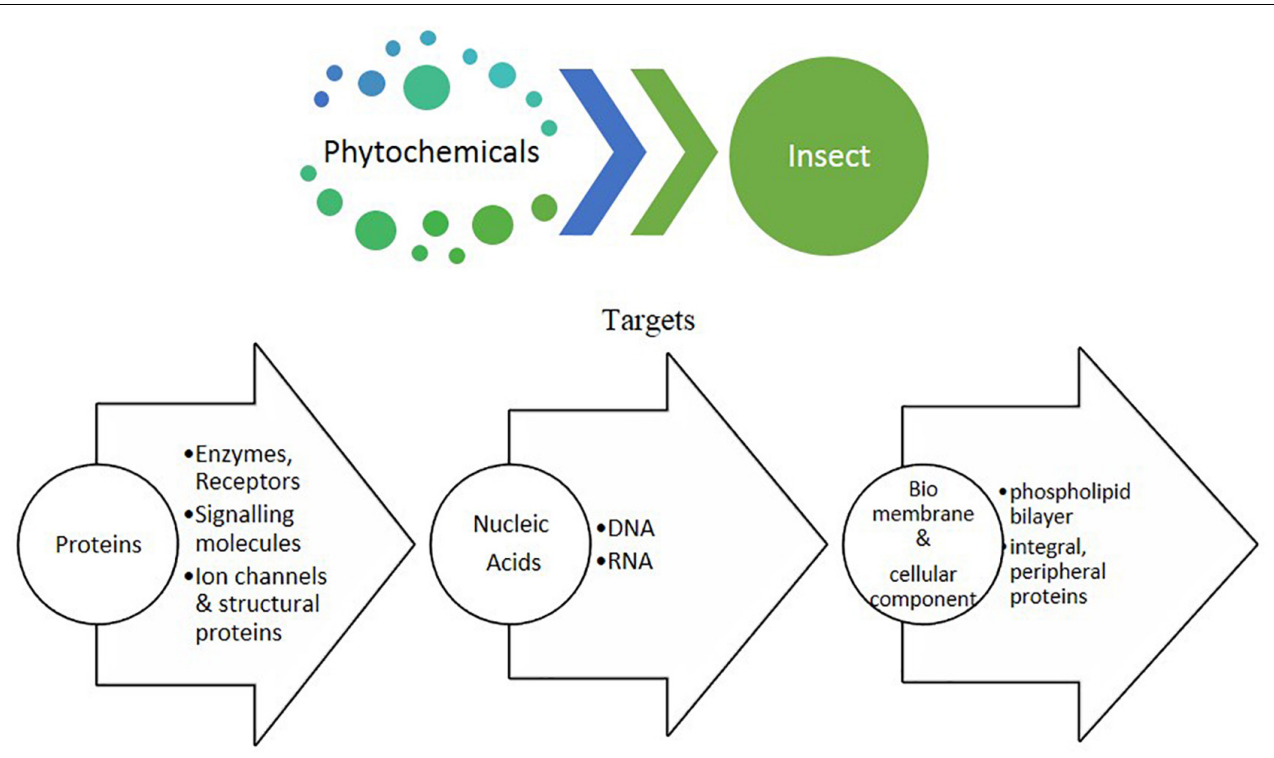

Affects insect Physiology

\begin{tabular}{ll}
\hline $\begin{array}{l}\text { Nervous system } \\
\text { abnormality - } \\
\text { Disruption of }\end{array}$ & $\begin{array}{l}\text { neurotransmitter synthesis, storage, } \\
\text { release, binding \& re-uptake }\end{array}$ \\
\cline { 2 - 2 } & $\begin{array}{l}\text { Receptor activation \& function, Enzymes } \\
\text { of signal transduction pathway }\end{array}$
\end{tabular}

Resulting

in

$\mathrm{AChE}$ inhibition

- Essential oils

GABA gated Chloride channel

- Thymol

Na \& K - ion exchange disruption

- Pyrethrin

Cellular Respiration inhibition

- Rotenone

\section{Calcium channel blockage}

- Ryanodine

Nerve cell membrane action disruption

- Sabadilla

Octopamine receptor disruption

- Thymol Mitotic poisoning \& hormonal balance

disruption

- Azadirachtin

\section{Disruption - molecular events \\ morphogenesis \& alteration in behaviour \& \\ memory - cholinergic system}

- Essential oils

FIGURE 1 | Mode of action of phytochemicals in insect body (modified after Ghosh et al., 2012).

paniculata (Acanthaceae) at the maximum dosage of $12 \mathrm{ppm}$ (Edwin et al., 2016). DDT resistance in the mosquito An. gambiae is correlated elevated glutathione transferase (GST) E2 activity (AgGSTE2) (Enayati et al., 2005). The DDT resistant An. gambiae evades the insecticidal activity by the dehydrochlorination of DDT to its non-insecticidal metabolite DDE. Muleya et al. (2008) reported that compounds -epiphyllocoumarin (Tral1), knipholone anthrone, isofuranonaphthoquinones ( $\mathrm{Mr} 13 / 2$, 
Mr13/4), and the polyprenylated benzophenone (GG1) were potent inhibitors of AgGSTE2.

Besides the botanical extracts, EO derived from the plants also have strong inhibition of detoxifying enzymes of arthropod vectors (Pavela, 2015). EOs may provide substitute sources of vector control since they are enriched with diverse phytomolecules with insecticidal properties (Cheng et al., 2013). Insecticide phytochemicals from EOs belong to terpenoids chiefly and Phenylpropanoids to a limited extent. In which, Terpenoids includes monoterpenes and sesquiterpenes as the major compositions of EOs (Chellappandian et al., 2018). Lee et al. (2003) specified that volatile and lipophilic monoterpenoids infiltrate insect body, where they afflict physiological processes, and hence their mode of action is hard to elucidate. Previous research of Vasantha-Srinivasan et al. (2017) showed that the CVO derived from Piper betle (L.) (Pb-CVO) showed upregulation in the level GST and CYP450 and down regulate the expression of Carboxylesterases activity against the field and laboratory strains of Ae. aegypti. Moreover, the above results also showed that the changes in the level of enzymes are steady in both field and laboratory strains compared to the chemical pesticides. Due to enriched chemical diversity and potential mosquitocidal activity, CVO have acquired greater interest from researchers looking for new besides natural replacements to chemical-pesticides in controlling medically challenging pests (Pavela, 2015). Correspondingly, EO constituent's nootkatone and carvacrol from Alaskan yellow cedar tree inhibits 50\% of acetylcholine esterase activity in Ae. aegypti compared to the carbaryl, a known acetylcholinesterase inhibitor (Anderson and Coats, 2012). The impact of major plant molecules against the mosquito larvicides was tabulated (Table 1). Hence, expression of these molecules on detoxifying and metabolic enzymes is considered an important biomarker to evaluate the mosquitocidal potential of bio-rational plant metabolites.

Pradeepa et al. (2014) have reported the antimalarial activities from the compound plumbagin, identified from the rhizome of Plumbago zeylanica against An. stephensi. Also, it was revealed that plumbagin constrains the vector AchE enzyme, An. Stephensi in a dose dependent manner and also can be considered for controlling resistant vectors whose insecticide resistance is associated to an increased SOD activity (Pradeepa et al., 2016). The detection of SOD activity in the anal gills of $A n$. stephensi larvae could be associated with their resistance provided against damaging oxygen products (Nivsarkar et al., 1991). The sensitivity of an insect to an insecticide can hence be increased by identifying certain compounds that can deactivate these enzymes (Larson et al., 2010).

\section{IMPACT OF PHYTOCHEMICALS ON MIDGUT TISSUES}

The midgut of the mosquito larvae is the chief interface of exterior environment and chip in major process like digestion, ion transport, absorption, and osmoregulation process (Bernick et al., 2008; Elumalai et al., 2016). Generally, gut region is the target of numerous insecticidal complexes and its integrity is dynamic for digestion and conferring of resistance against toxins (Stenfors Arnesen et al., 2008). With the insect midgut being the important site for synthesis of digestive enzymes, plant derived molecules primarily targets thee gut epithelium layer (EL) (Senthil-Nathan et al., 2008). This might be the significant cause for condensed metabolic rate in addition to a reduced enzyme activity (Selin-Rani et al., 2016). The peritrophic membrane (pM) gaurds the EL from the surrounding the gut lumen (GL) (Lija-Escaline et al., 2015). Phyto-chemicals are proven to exert a serious impact on the digestive epithelial cells and further decrease the growth rate of arthropods (Yu et al., 2015). Neira-Oviedo et al. (2008) stated that plant compounds flow into the gastric caeca and the malpighian tubules thereby affecting the midgut epithelium. For instance, extracts of $M$. azedarach have been reported to cause extensive harm on the EL and $\mathrm{pM}$ of filarial vector $C x$. quinquefasciatus (Al-Mehmadi and Al-Khalaf, 2010). The pM may influence the growth and development of parasites vectors by creating a mechanical barrier to invasion by ookinetes (Rudin and Hecker, 1989). Plant extracts and their metabolites are crucial for the impairment of pest mid-gut epithelium (Rey et al., 1999). The compound catechin isolated from Leucas aspera affects the mid-gut of the three mosquito larvae Ae. aegypti, An. stephensi, and Cx. quinquefasciatus (Elumalai et al., 2016). Previous photomicrographic study on the midgut tissues of the dengue mosquito (Field and laboratory strains of Ae. aegypti) treated with the CVO of $P$. betle displayed severe injuries to the GL and EL (Vasantha-Srinivasan et al., 2018). Correspondingly, leaf extracts of Aristolochia indica L. (Aristolochiaceae) and their derivatives aristolochic acid I and II showed severe damage on the midgut vacuolated gut epithelial columnar cells (epi), GL, and pM (Pradeepa et al., 2015). Likewise, methanolic leaf extracts of $P$. nigrum severely affected the midgut cellular organelles of Ae aegypti at the minimal dosage of $10 \mathrm{ppm}$ (Lija-Escaline et al., 2015). Similarly, Vasantha-Srinivasan et al. (2018) reported that $P$. betle CVO derived from $P$. betle at the sub-lethal dosage damage the $\mathrm{pM}$, and major alteration in the alignment of EL and GL of dengue mosquito comparable to the control. Previous research on Andrographolide a major derivative of $A$. paniculata against dengue mosquito gut cells proved that there was an unembellished collapse in the mid-gut $\mathrm{pM}$, in addition to a chief variation in the $\mathrm{El}$ and GL alignment (Edwin et al., 2016). Selin-Rani et al. (2016) reported that the active plant molecules may damage the gut epithelium is the vital reason for concentrated metabolic rate and decrease in the enzyme-activity. Midgut cell damage is directly linked to the digestive and detoxifying enzymes dysregulation (SenthilNathan et al., 2008). This was also confirmed by histological studies of the mosquitoes that displayed midgut cell damage, post treatment with various botanical compounds (Yu et al., 2015). Further, treatment with plant compounds were also associated with altered protein (Fallatah, 2014) and biochemical profiles in mosquitoes (Senthilkumar et al., 2013).

Biochemical studies on Cx. pipipens exposed to Allium satvium, Citrus limon, and Bti were observed by Saeed et al. (2010). Results revealed that the use of plant oil extracts and Bti have great effect on total protein content of treated mosquito 
larvae. Fallatah (2010) reported the effect of water extract of fenugreek have high larvicidal effect against $C x$. quinquefasciatus, causing noticeable effects on numerous body tissues together with the midgut and nervous system as well as total protein content. Aristolochic acids isolated from A. indica Linn, mainly affected the midgut EL and secondly the larval muscles and cells (Pradeepa et al., 2015). Similar results were also observed in mosquitoes treated with plant extracts (Costa et al., 2012). The orientation of the cytoplasmic protrusions of the apical surfaces of columnar cells toward the lumen suggests the secretion of apocrine and/or apoptosis.

Al-Mekhlafi (2018) reported the effect of Arum copticum (Apiaceae) extract against Culex pipiens larvae. Apart from exhibiting larvicidal activity, the extract was able to display cytopathological alterations of the midgut epithelium. EO and enriched fraction of Peumus boldus displayed larvicidal activity against Cu. Quinquefasciatus. The treated larvae displayed morphological changes in the midgut cells (de Castro et al., 2016). Velu et al. (2015) tested the peel extract of $A$. hypogaea against Aedes aegypti and Anopheles stephensi. The histopathological studies exposed midgut tissue damage and cuticle injury. Costa et al. (2012) reported similar aberrations in Ae. aegypti larvae (III instar) treated with Annona coriacea extract. Ae. aegypti larvae exposed to squamocin from Annona mucosa Jacq. (Annonaceae) displayed larvicidal and cytotoxic action with changes in the midgut epithelium and digestive cells by increasing the expression of autophagy genes (Costa et al., 2014, 2017). da Silva Costa et al. (2018) also reported that squamocin affected the osmoregulation and ion-regulation of Ae. aegypti larvae which resulted in a lethal effect caused by the development of a great vacuolization in the anal papillae wall.

The histopathological study of Ae. aegypti treated with methanol extract derived from seaweeds Sargassum binderi showed that larvae treated with seaweed extracts had cytopathological alteration of the midgut epithelium. The morphological observation revealed that the anal papillae and terminal spiracles of larvae were the common sites of aberrations (Yu et al., 2015). Phytochemicals (oleic, linoleic, linolenic, palmitic, and stearic acids) and their respective methyl esters were tested against fourth instar $\mathrm{Cu}$. quinquefasciatus larvae. The compounds were found to affect its metabolism and the morphology of midgut along with their fat body (de Melo et al., 2018).

\section{IMPACT OF PHYTOCHEMICALS ON THE INSECT BEHAVIOR}

With the development of resistance by this time attained to almost all available chemicals, strategies integrating "plant derived" compounds to influence "semiochemical"-mediated behaviors by means of interruption of mosquito-olfactory sensory system have substantially developed (Muema et al., 2017). As a consequence, the physiological status related to the olfactory sensory system is disrupted. The phytochemicals will bind to these odorant chemoreceptors and subsequent flight orientations of the mosquitoes are hindered (Bohbot et al., 2010). Henceforth the physiological status for instance "circadian-regulated appetitive stimulus" or "gonotrophic status" that triggers olfaction in pursuit of nutritious sources, mates and oviposition sites are disturbed. Plant-based semiochemicals can be exploited to lure the mosquitoes to an insecticide trap, thereby forming an integral part of an integrated vector control programe (Kamala-Jayanthi et al., 2015). Rice volatiles on evaluation with BioGent (BG) sentinel traps elicited antennal responses that stimulated long range oviposition site seeking behavior. Also, p-cresol, from Bermuda grass hay infusion was reported with avoidance response to gravid An. Gambiae (Eneh et al., 2016).

\section{FUTURE PERSPECTIVES}

Higher rates of anthropogenic activities that are expected to expand with the population increase will increase the incidence of vector borne diseases. Additionally, the development of resistance among the vector population against the synthetic chemical insecticides along with their persistence in the environment and toxicity for non-target organisms are reducing the efficiencies of vector management practices globally. Hence novel plant-based compounds that are safe and effective are being focused for the development of improved management of vectors.

The research has now moved on from the isolation of bioactive compounds with anti-vector potentials to formulate novel application methods. Apart from the direct application of plant metabolites in vector control, nanoparticles (NPs) synthesized from plants using green technology are emerging as a new trend. Nanotechnology is presently "revolutionizing" the manufacture of commercial pesticides. Production of green NPs and nanoencapsulation compounds upsurges the permanence of EOs through "slow-release" phenomenon deliberating sustained fortification against mosquito bites. As reported by Jinu et al. (2018), silver nanoparticles (AgNPs) from Cleistanthus collinus Karra and Strychnos nux-vomica Linn nux-vomica presented highest larvicidal activity against $A$. stephensi and $A$. aegypti. Murugan et al. (2018a,b) proved the efficacy of zinc oxide NPs fabricated using the brown macroalga Sargassum wightii Greville ex J. Agardh. against An. stephensi. In another study reported by Murugan et al. (2018b), Poly (Styrene Sulfonate)/Poly (allylamine hydrochloride) encapsulation of $\mathrm{TiO}_{2}$ NPs were found to enhance their toxicity against mosquito vectors of Zika virus.

\section{CONCLUSION}

Mosquito vector borne diseases are a major human health problem in all countries. There has been an alteration toward plant-based insecticides to overcome the problems related with the use of synthetic mixtures in mosquito control programe. Botanicals can be used as mosquitocides for killing both larvae and adult mosquitoes. However, only very few botanicals have moved from laboratory to the field use, which may be due to the light and heat variability of phytochemicals compared to synthetic insecticides. Further these botanicals have been widely explored, but only a comparatively small number of patents have 
been filed with the persistence of regulating the formulations for use against mosquito species in the field level.

Although the activity of phytochemicals are generally attributed to some specific compounds, but there is increasing evidence that the combination of botanicals and biopesticides will result in an increased bioactivity compared to single phytochemicals (Senthil-Nathan et al., 2005a; Senthil-Nathan and Kalaivani, 2005, 2006).

At present, botanical insecticides make $<1 \%$ of the world's pesticide market (Sola et al., 2014). Isolation of active principles and synthesis of secondary metabolites of botanicals against mosquito threat are very important for the management of vector borne diseases. The positive results of initial studies on larvicidal potential of botanicals encourage further interest to investigate the bioactive compounds. Identifying botanical insecticides that are effective as well as appropriate and adaptive to overcome ecological hazards, biodegradable, and have a broad spectrum of larvicidal properties will work as a new defense in the arsenal of insecticides and it may act as an appropriate alternative product to fight against vector-borne diseases.

\section{REFERENCES}

Aciole, S. D., Piccoli, C. F., Costa, E. V., Navarro-Silva, M. A., Marques, F. A., Sales Maia, B. H., et al. (2011). Insecticidal activity of three species of Guatteria (Annonaceae) against Aedes aegypti (Diptera: Culicidae). Rev. Colomb. Entomol. 37, 262-268.

Aciole, S. D. G. (2009). Avaliação da Actividade Insecticida Dos Óleos Essenciais Nas Plantas Amazônicas Annonaceae, Boraginaceae e de Mata Atlântica Myrtaceae como Alternativa De Controle às Larvas de Aedes aegypti (Linnaeus, 1762) (Diptera: Culicidae). Doctoral dissertation, Universidade de lisboa, Lisbon.

Agra-Neto, A. C., Napoleão, T. H., Pontual, E. V., Santos, N. D. L., Luz, L. A., Oliveira, C. M. F., et al. (2014). Effect of moringa oleifera lectins on survival and enzyme activities of Aedes aegypti larvae susceptible and resistant to organophosphate. Parasitol. Res. 113, 175-184. doi: 10.1007/s00436-0133640-8

Aguiar, J. C. D., Santiago, G. M., Lavor, P. L., Veras, H. N., Ferreira, Y. S., Lima, M. A., et al. (2010). Chemical constituents and larvicidal activity of hymenaea courbaril fruit peel. Nat. Prod. Commu. 5, 1977-1980.

Aguilera, L., Navarro, A., Tacoronte, J. E., Leyva, M., and Marquetti, M. C. (2003). Efecto letal de myrtaceas cubanas sobre Aedes aegypti (Diptera: Culicidae). Rev. Cub. Med. Trop. 55, 100-104.

Albuquerque, M. R. J. R., Costa, S. M. O., Bandeira, P. N., Santiago, G. M. P., Andrade-Neto, M., Silveira, E. R., et al. (2007). Nematicidal and larvicidal activities of the essential oils from aerial parts of Pectis oligocephala and Pectis apodocephala Baker. An. Acad. Bras. Ciênc. 79, 209-213. doi: 10.1590/s000137652007000200003

Albuquerque, M. R. J. R., Silveira, E. R., De, A., Uchôa, D. E., Lemos, T. L. G., Souza, E. B., et al. (2004). Chemical composition and larvicidal activity of the essential oils from Eupatorium betonicaeforme (DC) Baker (Asteraceae). J. Agric. Food Chem. 52, 6708-6711. doi: 10.1021/jf0352881

Ali, A., Tabanca, N., Demirci, B., Baser, K. H. C., Ellis, J., Gray, S., et al. (2013). Composition, mosquito larvicidal, biting deterrent and antifungal activity of essential oils of different plant parts of Cupressus arizonica var. glabra ('Carolina Sapphire'). Nat. Prod. Commun. 8, 257-260. doi: 10.1177/1934578X1300800232

Al-Mehmadi, R. M., and Al-Khalaf, A. A. (2010). Larvicidal and histological effects of melia azedarach extract on Culex quinquefasciatus say larvae (Diptera: Culicidae). J. King Saud. Univ. Sci. 22, 77-85. doi: 10.1016/j.jksus.2010. 02.004

Al-Mekhlafi, F. A. (2018). Larvicidal, ovicidal activities and histopathological alterations induced by Carum copticum (Apiaceae) extract against Culex pipiens (Diptera: Culicidae). Saudi J. Biol. Sci. 25, 52-56. doi: 10.1016/j.sjbs.2017.02.010
Thus, the present review collects important information on plant extracts along with their active molecules as agents affecting the physiology and behavior of medically threatening mosquito vectors. Now collective efforts are needed to take advantage of the accumulated knowledge on phytochemical action on mosquitos in order to integrate their application in integrated pest management programs.

\section{AUTHOR CONTRIBUTIONS}

SS-N collected all the information and wrote the review.

\section{ACKNOWLEDGMENTS}

I am very grateful to Dr. Sylvia Anton for her thorough and constructive review and suggestion on the first draft of the manuscript.

Amer, A., and Mehlhorn, H. (2006). Repellency effect of forty-one essential oils against Aedes, Anopheles, and Culex mosquitoes. Parasitol. Res. 99:478. doi: 10.1007/s00436-006-0184-1

Anderson, J. A., and Coats, J. R. (2012). Acetylcholinesterase inhibition by nootkatone and carvacrol in arthropods. Pestic. Biochem. Physiol. 102, 124-128. doi: 10.1016/j.pestbp.2011.12.002

Ansari, M., Mittal, P., Razdan, R., and Sreehari, U. (2005). Larvicidal and mosquito repellent activities of pine (pinus longifolia, family: pinaceae) oil. J. Vector Borne Dis. 42:95.

Araújo, E. C., Silveira, E. R., Lima, M. A. S., Neto, M. A., de Andrade, I. L., Lima, M. A. A., et al. (2003). Insecticidal activity and chemical composition of volatile oils from hyptis martiusii Benth. J. Agri. Food Chem. 51, 3760-3762. doi: $10.1021 /$ jf021074s

Arriaga, A. M., Rodrigues, F. E., Lemos, T. L., de Oliveira, M. D. C., Lima, J. Q., Santiago, G. M., et al. (2007). Composition and larvicidal activity of essential oil from stemodia maritima L. Nat. Prod. Commun. 2, 1237-1239.

Autran, E., Neves, I., Da Silva, C., Santos, G., Da Câmara, C., and Navarro, D. (2009). Chemical composition, oviposition deterrent and larvicidal activities against Aedes aegypti of essential oils from Piper marginatum Jacq (Piperaceae). Biores. Technol. 100, 2284-2288. doi: 10.1016/j.biortech.2008.10.055

Balasubramani, G., Ramkumar, R., Krishnaveni, N., Sowmiya, R., Deepak, P., Arul, D., et al. (2015). GC-MS analysis of bioactive components and synthesis of gold nanoparticle using Chloroxylon swietenia DC leaf extract and its larvicidal activity. J. Photochem. Photobiol B: Biol. 148, 1-8. doi: 10.1016/j.jphotobiol. 2015.03.016

Bandara, K. P., Kumar, V., Jacobsson, U., and Molleyres, L.-P. (2000). Insecticidal piperidine alkaloid from Microcos paniculata stem bark. Phytochemistry 54, 29-32. doi: 10.1016/S0031-9422(00)00025-X

Banerji, B., and Nigam, S. (1984). Wood constituents of meliaceae: a review. Fitoter $55,3-36$.

Baraza, L. D., Joseph, C. C., Munissi, J. J. E., Nkunya, M. H. H., Arnold, N., Porzel, A., et al. (2008). Antifungal rosane diterpenes and other constituents of Hugonia castaneifolia. Phytochemistry 69, 200-205. doi: 10.1016/j.phytochem.2007.06. 021

Benelli, G., Pavela, R., Canale, A., Cianfaglione, K., Ciaschetti, G., Conti, F., et al. (2017). Acute larvicidal toxicity of five essential oils (Pinus nigra, Hyssopus officinalis, Satureja montana, Aloysia citrodora and Pelargonium graveolens) against the filariasis vector Culex quinquefasciatus: synergistic and antagonistic effects. Parasitol. Inter. 66, 166-171. doi: 10.1016/j.parint.2017.01.012

Benelli, G., Pavela, R., Petrelli, R., Cappellacci, L., Canale, A., Senthil-Nathan, S., et al. (2018). Not just popular spices! essential oils from Cuminum cyminum and 
Pimpinella anisum are toxic to insect pests and vectors without affecting nontarget invertebrates. Indus. Crop. Prod. 124, 236-243. doi: 10.1016/j.indcrop. 2018.07.048

Bernick, E. P., Moffett, S. B., and Moffett, D. F. (2008). Ultrastructure and morphology of midgut visceral muscle in early pupal Aedes aegypti mosquitoes. Tissue Cell 40, 127-141. doi: 10.1016/j.tice.2007.11.001

Bohbot, J. D., Lu, T., and Zwiebel, L. J. (2010). Molecular Regulation of Olfaction In Mosquitoes. Olfaction in Vector-Host Interactions. Wageningen: Wageningen Academic Publishers, 17-38.

Bora, K. S., and Sharma, A. (2011). The genus Artemisia: a comprehensive review. Pharm. Biol. 49, 101-109. doi: 10.3109/13880209.2010.497815

Borah, R., Saikia, K., Talukdar, A. K., and Kalita, M. C. (2012). Chemical composition and biological activity of the leaf essential oil of Zanthoxylum oxyphyllum. Planta Med. 78:100. doi: 10.1055/s-0032-1307608

Brown, A. W. (1986). Insecticide resistance in mosquitoes: a pragmatic review. J. Amer. Mosq. Control Assoc. 2, 123-140.

Burfield, T. (2000). Safety of essential oils. Inter. J. Arom. 10, 16-29.

Caballero, R., Hoshi, T., and Kashyap, A. (2008). Zombie lending and depressed restructuring in Japan. Am. Econ. Rev. 98, 1943-1977. doi: 10.1257/aer.98.5. 1943

Carreño-Otero, A. L., Palacio-Cortés, A. M., Navarro-Silva, M. A., Kouznetsov, V. V., Duque, L. J. E., and Jonny, E. (2018). Behavior of detoxifying enzymes of Aedes aegypti exposed to girgensohnine alkaloid analog and Cymbopogon flexuosus essential oil. Comp. Biochem. Physiol. Part C 204, 14-25. doi: 10.1016/ j.cbpc.2017.11.002

Cavalcanti, E. S. B., Morais, S. M. D., Lima, M. A., and Santana, E. W. P. (2004). Larvicidal activity of essential oils from Brazilian plants against Aedes aegypti L. Mem. Instit. Oswaldo Cruz 99, 541-544. doi: 10.1590/S007402762004000500015

Cetin, H., Yanikoglu, A., and Cilek, J. E. (2011). Larvicidal activity of selected plant hydrodistillate extracts against the house mosquito, Culex pipiens, a West Nile virus vector. Parasitol. Res. 108, 943-948. doi: 10.1007/s00436-010-2136-z

Chauret, D. C., Bernard, C. B., Arnason, J. T., Durst, T., Krishnamurty, H., Sanchez-Vindas, P., et al. (1996). Insecticidal neolignans from Piper decurrens. J. Nat. Prod. Res. 59, 152-155. doi: 10.1021/np960036y

Chellappandian, M., Senthil-Nathan, S., Vasantha-Srinivasan, P., Karthi, S., Thanigaivel, A., Kalaivani, K., et al. (2019). Target and non-target botanical pesticides effect of Trichodesma indicum (Linn) R. Br. and their chemical derivatives against the dengue vector, Aedes aegypti L. Environ. Sci. Poll. Res. 26, 16303-16315. doi: 10.1007/s11356-019-04870-3

Chellappandian, M., Thanigaivel, A., Vasantha-Srinivasan, P., Edwin, E. S., Ponsankar, A., Selin-Rani, S., et al. (2017). Toxicological effects of Sphaeranthus indicus linn (asteraceae) leaf essential oil against human disease vectors, Culex quinquefasciatus say and Aedes aegypti linn., and impacts on a beneficial mosquito predator. Environ. Sci. Poll. Res. 25, 10294-10306. doi: 10.1007/ s11356-017-8952-2

Chellappandian, M., Vasantha-Srinivasan, P., Senthil-Nathan, S., Karthi, S., Thanigaivel, A., Ponsankar, A., et al. (2018). Botanical essential oils and uses as mosquitocides and repellents against dengue. Environ. Intern. 113, 214-230. doi: 10.1016/j.envint.2017.12.038

Cheng, S. S., Chang, H. T., Lin, C. Y., Chen, P. S., Huang, C. G., Chen, W. J., et al. (2009a). Insecticidal activities of leaf and twig essential oils from Clausena excavata against Aedes aegypti and Aedes albopictus larvae. Pestic. Manag. Sci. 65, 339-343. doi: 10.1002/ps.1693

Cheng, S. S., Chua, M. T., Chang, E. H., Huang, C. G., Chen, W. J., and Chang, S. T. (2009b). Variations in insecticidal activity and chemical compositions of leaf essential oils from Cryptomeria japonica at different ages. Bioresour. Technol. 100, 465-470. doi: 10.1016/j.biortech.2007.11.060

Cheng, S. S., Huang, C. G., Chen, Y. J., Yu, J. J., Chen, W. J., and Chang, S. T. (2009c). Chemical compositions and larvicidal activities of leaf essential oils from two Eucalyptus species. Bioresour. Technol. 100, 452-456. doi: 10.1016/ j.biortech.2008.02.038

Cheng, S. S., Lin, C. Y., Chung, M. J., Liu, Y. H., Huang, C. G., and Chang, S. T. (2013). Larvicidal activities of wood and leaf essential oils and ethanolic extracts from Cunninghamia konishii Hayata against the dengue mosquitoes. Ind. Crops Prod. 47, 310-315. doi: 10.1016/j.indcrop.2013.03.016

Cheng, S. S., Liu, J. Y., Tsai, K. H., Chen, W. J., and Chang, S. T. (2004). Chemical composition and mosquito larvicidal activity of essential oils from leaves of different Cinnamomum osmophloeum provenances. J. Agri. Food Chem. 52, 4395-4400. doi: 10.1021/jf0497152

Choochote, W., Chaiyasit, D., Kanjanapothi, D., Rattanachanpichai, E., Jitpakdi, A., Tuetun, B., et al. (2005). Chemical composition and anti-mosquito potential of rhizome extract and volatile oil derived from Curcuma aromatica against Aedes aegypti (Diptera: Culicidae). J. Vector Biol. 30, 302-309.

Chung, I. M., Seo, S. H., Kang, E. Y., Park, S. D., Park, W. H., and Moon, H. I. (2009). Chemical composition and larvicidal effects of essential oil of Dendropanax morbifera against Aedes aegypti L. Biochem. Syst. Ecol. 37, 470-473. doi: 10.1016/j.bse.2009.06.004

Clark, A. G. (1990). "The glutathione S-transferases and resistance to insecticides," in Glutathione S-transferases and Drug Resistance, eds J. D. Hayes, C. B. Pickett, and T. J. Mantle, (London: Taylor and Francis), 369-378.

Conti, B., Canale, A., Bertoli, A., Gozzini, F., and Pistelli, L. (2010). Essential oil composition and larvicidal activity of six mediterranean aromatic plants against the mosquito Aedes albopictus (Diptera: Culicidae). Parasitol. Res. 107, 1455-1461. doi: 10.1007/s00436-010-2018-4

Costa, J. G., Pessoa, O. D., Menezes, E. A., Santiago, G. M., and Lemos, T. L. (2004). Composition and larvicidal activity of essential oils from heartwood of Auxemma glazioviana taub (Boraginaceae). Flav. Frag. J. 19, 529-531. doi: 10.1002/ffj. 1332

Costa, J. G. M., Rodrigues, F. F. G., Angélico, E. C., Silva, M. R., Mota, M. L., Santos, N. K. A., et al. (2005). Estudo químico-biológico dos óleos essenciais de hyptis martiusii, lippia sidoides e Syzigium aromaticum frente às larvas do Aedes aegypti. Rev. Bras. Farmacogn. 15, 304-309.

Costa, J. G. M., Rodrigues, F. F. G., Sousa, E. O., Junior, D. M. S., Campos, A. R., Coutinho, H. D. M., et al. (2010). Composition and larvicidal activity of the essential oils of Lantana camara and Lantana montevidensis. Chem. Nat. Comp. 46, 313-315. doi: 10.1007/s10600-010-9601-x

Costa, M., Cossolin, J., Pereira, M., Sant'Ana, A., Lima, M., Zanuncio, J., et al. (2014). Larvicidal and cytotoxic potential of squamocin on the midgut of Aedes aegypti (Diptera: Culicidae). Toxins 6, 1169-1176. doi: 10.3390/toxins604 1169

Costa, M. S., Pinheiro, D. O., Serrão, J. E., and Pereira, M. J. B. (2012). Morphological changes in the midgut of Aedes aegypti L. (Diptera: Culicidae) larvae following exposure to an Annona coriacea (Magnoliales: Annonaceae) extract. Neotrop. Entomol. 41, 311-314. doi: 10.1007/s13744-012050-Z

Costa, M. S., Santana, A. E., Oliveira, L. L., Zanuncio, J. C., and Serrão, J. E. (2017). Toxicity of squamocin on Aedes aegypti larvae, its predators and human cells. Pestic. Manag. Sci. 73, 636-640. doi: 10.1002/ps.4350

da Silva Costa, M., de Paula, S. O., Martins, G. F., Zanuncio, J. C., Santana, A. E. G. and Serrão, J. E. (2018). Modes of action of squamocin in the anal papillae of Aedes aegypti larvae. Physiol. Mol. Plant Pathol. 101, 172-177. doi: 10.1016/j. pmpp.2017.04.001

David, J. P., Ismail, H. M., Chandor-Proust, A., and Paine, M. J. I. (2013). Role of cytochrome P450s in insecticide resistance: impact on the control of mosquitoborne diseases and use of insecticides on Earth. Philos Trans. R Soc. Lond B Biol. Sci. 3:68. doi: 10.1098/rstb.2012.0429

de Castro, D. S. B., da Silva, D. B., Tibúrcio, J. D., Sobral, M. E. G., Ferraz, V., Taranto, A. G., et al. (2016). Larvicidal activity of essential oil of Peumus boldus Molina and its ascaridole-enriched fraction against Culex quinquefasciatus. Exp. Parasitol. 171, 84-90. doi: 10.1016/j.exppara.2016.10.008

de Melo, A. R., Garcia, I. J. P., Serrão, J. E., Santos, H. L., dos Santos Lima, L. A. R., and Alves, S. N. (2018). Toxicity of different fatty acids and methyl esters on Culex quinquefasciatus larvae. Ecotoxicol. Environ. Saf. 154, 1-5. doi: 10.1016/j.ecoenv.2018.02.009

de Morais, S. M., Facundo, V. A., Bertini, L. M., Cavalcanti, E. S. B., Dos Anjos Júnior, J. F., Ferreira, S. A., et al. (2007). Chemical composition and larvicidal activity of essential oils from Piper species. Biochem. Syst. Ecol. 35, 670-675. doi: 10.1016/j.bse.2007.05.002

Dharmagadda, V. S. S., Naik, S. N., Mittal, P. K., and Vasudevan, P. (2005). Larvicidal activity of Tagetes patula essential oil against three mosquito species. Bioresour. Technol. 96, 1235-1240. doi: 10.1016/j.biortech.2004.10.020

do Nascimento, J. C., David, J. M., Barbosa, L. C., De Paula, V. F., Demuner, A. J., David, J. P., et al. (2013). Larvicidal activities and chemical composition of essential oils from Piper klotzschianum (Kunth) C. DC. (Piperaceae). Pestic. Manag. Sci. 69, 1267-1271. doi: 10.1002/ps.3495 
Dua, V. K., Kumar, A., Pandey, A. C., and Kumar, S. (2013). Insecticidal and genotoxic activity of Psoralea corylifolia Linn (Fabaceae) against Culex quinquefasciatus Say, 1823. Parasit. Vectors 6:30. doi: 10.1186/1756-3305-6-30

Edwin, E.-S., Vasantha-Srinivasan, P., Senthil-Nathan, S., Thanigaivel, A., Ponsankar, A., Pradeepa, V., et al. (2016). Anti-dengue efficacy of bioactive andrographolide from Andrographis paniculata (Lamiales: Acanthaceae) against the primary dengue vector Aedes aegypti (Diptera: Culicidae). Acta Trop. 163, 167-178. doi: 10.1016/j.actatropica.2016.07.009

Elumalai, D., Kaleena, P. K., Ashok, K., Suresh, A., and Hemavathi, M. (2016). Green synthesis of silver nanoparticle using Achyranthes aspera and its larvicidal activity against three major mosquito vectors. Eng. Agric. Environ. Food 9, 1-8. doi: 10.1016/j.eaef.2015.08.002

Enayati, A. A., Ranson, H., and Hemingway, J. (2005). Mini review: insectglutathione transferases and insecticide resistance. Insect. Mol. Biol. 14, 3-8. doi: 10.1111/j.1365-2583.2004.00529.x

Eneh, L. K., Okal, M. N., Borg-Karlson, A. K., Fillinger, U., and Lindh, J. M. (2016). Gravid Anopheles gambiae sensu stricto avoid ovipositing in Bermuda grass hay infusion and it's volatiles in two choice egg-count bioassays. Malaria J. 15:276. doi: 10.1186/s12936-016-1330-6

Evergetis, E., Michaelakis, A., and Haroutounian, S. A. (2012). Essential Oils of Umbelliferae (Apiaceae) Family Taxa as Emerging Potent Agents for Mosquito Control. London: InTechOpen.

Evergetis, E., Michaelakis, A., Kioulos, E., Koliopoulos, G., and Haroutounian, S. (2009). Chemical composition and larvicidal activity of essential oils from six Apiaceae family taxa against the West Nile virus vector Culex pipiens. Parasitol. Res. 105, 117-124. doi: 10.1007/s00436-009-137

Fallatah, H. I. (2014). Noninvasive biomarkers of liver fibrosis: an overview. $A d v$. Hepatol. 2014:8. doi: 10.1155/2014/357287

Fallatah, S. A. (2010). Histopathological effects of fenugreek (Trigonella foenumgraceum) extracts on the larvae of the mosquito Culex quinquefasciatus. J. Arab Soc. Med. Res. 5, 123-130.

Fayemiwo, K. A., Adeleke, M. A., Okoro, O. P., Awojide, S. H., and Awoniyi, I. O. (2014). Larvicidal efficacies and chemical composition of essential oils of Pinus sylvestris and Syzygium aromaticum against mosquitoes. Asian Pac. J. Trop. Biomed. 4, 30-34. doi: 10.1016/S2221-1691(14)60204-5

Feitosa, E., Arriaga, A., Santiago, G. M., De Lemos, T. L., and Oliveira, M. C. F. (2009). Chemical composition and larvicidal activity of Rollinia leptopetala (Annonaceae). J. Braz. Chem. Soc. 20, 375-378. doi: 10.1590/S010350532009000200024

Feitosa, E. M. A., Arriaga, A. M. C., Lemos, T. L. G., Lima, J. Q., Nunes Vasconcelos, J., Oliveira, M. C. F., et al. (2007). Zanthoxylum articulatum engler (Rutaceae) essential oil: chemical composition and larvicidal activity. J. Essen. Oil Res. 19, 384-386. doi: 10.1080/10412905.2007.9699311

Fradin, M. S., and Day, J. F. (2002). Comparative efficacy of insect repellents against mosquito bites. New Engl. J. Med. 347, 13-18. doi: 10.1056/NEJMoa011699

François, G., van Looveren, M., Timperman, G., Chimanuka, B., Akéassi, L., Holenz, J., et al. (1996). Larvicidal activity of the naphthylisoquinoline alkaloid dioncophylline a against the malaria vector Anopheles stephensi. J. Ethnopharm. 54, 125-130. doi: 10.1016/S0378-8741(96)01459-6

Gbolade, A. A., and Lockwood, G. B. (2008). Toxicity of Ocimum sanctum L. essential oil to Aedes aegypti larvae and its chemical composition. J. Essen. Oil Bear. Plants 11, 148-153. doi: 10.1080/0972060X.2008.10643611

Ghosh, A., Chowdhury, N., and Chandra, G. (2012). Plant extracts as potential mosquito larvicides. Ind. J. Med. Res. 135:581.

Giatropoulos, A., Kimbaris, A., Michaelakis, A., Papachristos, D. P., Polissiou, M. G., and Emmanouel, N. (2018). Chemical composition and assessment of larvicidal and repellent capacity of 14 Lamiaceae essential oils against Aedes albopictus. Parasitol. Res. 117, 1953-1964. doi: 10.1007/s00436-0185892-9

Giatropoulos, A., Pitarokili, D., Papaioannou, F., Papachristos, D. P., Koliopoulos, G., Emmanouel, N., et al. (2013). Essential oil composition, adult repellency and larvicidal activity of eight Cupressaceae species from Greece against Aedes albopictus (Diptera: Culicidae). Parasitol. Res. 112, 1113-1123. doi: 10.1007/ s00436-012-3239-5

Govindarajan, M., and Benelli, G. (2016). Artemisia absinthium-borne compounds as novel larvicides: effectiveness against six mosquito vectors and acute toxicity on non-target aquatic organisms. Parasitol. Res. 115, 4649-4661. doi: 10.1007/ s00436-016-5257-1
Govindarajan, M., Rajeswary, M., and Benelli, G. (2016). Chemical composition, toxicity and non-target effects of Pinus kesiya essential oil: an eco-friendly and novel larvicide against malaria, dengue and lymphatic filariasis mosquito vectors. Ecotoxicol. Environ. Saf. 129, 85-90. doi: 10.1016/j.ecoenv.2016.03.007

Govindarajan, M., Sivakumar, R., Rajeswari, M., and Yogalakshmi, K. (2012). Chemical composition and larvicidal activity of essential oil from Mentha spicata (Linn.) against three mosquito species. Parasitol. Res. 110, 2023-2032. doi: 10.1007/s00436-011-2731-7

Govindarajan, M., Sivakumar, R., Rajeswary, M., and Veerakumar, K. (2013). Mosquito larvicidal activity of thymol from essential oil of Coleus aromaticus benth. Against Culex tritaeniorhynchus, Aedes albopictus, and Anopheles subpictus (Diptera: Culicidae). Parasitol. Res. 112, 3713-3721. doi: 10.1007/ s00436-013-3557-2

Hemingway, J., Hawkes, N., Mccarroll, L., and Ranson, H. (2004). The molecular basis of insecticide resistance in mosquitoes. Insect. Biochem. Mol. Biol. 34, 653-655. doi: 10.1016/j.ibmb.2004.03.018

Hemingway, J., and Ranson, H. (2000). Insecticide resistance in insect vectors of human disease. Annu. Rev. Entomol. 45, 371-391. doi: 10.1146/annurev.ento. 45.1.371

Heuskin, S., Godin, B., Leroy, P., Capella, Q., Wathelet, J. P., Verheggen, F., et al. (2009). Fast gas chromatography characterisation of purified semiochemicals from essential oils of Matricaria chamomilla L. (Asteraceae) and Nepeta cataria L.(Lamiaceae). J. Chromatograph. A 1216, 2768-2775. doi: 10.1016/j.chroma. 2008.09.109

Hong, S., Guo, Q., Wang, W., Hu, S., Fang, F., Lv, Y., et al. (2014). Identification of differentially expressed micro RNAs in Culexpipiens and their potential roles in pyrethroid resistance. Insect. Biochem. Mol. Biol. 55, 39-50. doi: 10.1016/j.ibmb. 2014.10.007

Ioset, J. R., Marston, A., Gupta, M. P., and Hostettmann, K. (2000). Antifungal and larvicidal cordiaquinones from the roots of Cordia curassavica. Phytochem. 53, 613-617. doi: 10.1016/S0031-9422(99)00604-4

Jaenson, T. G., Pålsson, K., and Borg-Karlson, A. K. (2006). Evaluation of extracts and oils of mosquito (Diptera: Culicidae) repellent plants from Sweden and Guinea-Bissau. J. Med. Entomol. 43, 113-119. doi: 10.1093/jmedent/43.1.113

Jantan, I. B., Yalvema, M. F., Ahmad, N. W., and Jamal, J. A. (2005). Insecticidal activities of the leaf oils of eight Cinnamomum. species against Aedes aegypti and Aedes albopictus. Pharm. Biol. 43, 526-532. doi: 10.1080/ 13880200500220771

Jayaprakasha, G., Singh, R., Pereira, J., and Sakariah, K. (1997). Limonoids from Citrus reticulata and their moult inhibiting activity in mosquito Culex quinquefasciatus larvae. Phytochemistry 44, 843-846. doi: 10.1016/S00319422(96)00589-4

Jinu, U., Rajakumaran, S., Senthil-Nathan, S., Geetha, N., and Venkatachalam, P. (2018). Potential larvicidal activity of silver nanohybrids synthesized using leaf extracts of Cleistanthus collinus (Roxb.) Benth. ex Hook. f. and Strychnos nuxvomica L. nux-vomica against dengue, Chikungunya and Zika vectors. Physiol. Mol. Plant Pathol. 101, 163-171. doi: 10.1016/j.pmpp.2017.05.003

Jones, G., Smith, J., and Watson, K. (2007). "Bioactive properties of native Australian medicinal plants," in Advances in Medicinal Plant Research, eds S. N. Acharya and J. E. Thomas (Thiruvananthapuram: Research Signpost), 257-286.

Joseph, C. C., Ndoile, M. M., Malima, R. C., and Nkunya, M. H. H. (2004). Larvicidal and mosquitocidal extracts, a coumarin, isoflavonoids and pterocarpans from neorautanenia mitis. Trans. R. Soc.Trop. Med. Hyg. 98, 451-455. doi: 10.1016/j.trstmh.2003.10.008

Jukic, M., Politeo, O., Maksimovic, M., Milos, M., and Milos, M. (2007). In Vitro acetylcholinesterase inhibitory properties of thymol, carvacrol and their derivatives thymoquinone and thymohydroquinone. Phytother. Res. 21, 259261. doi: 10.1002/ptr.2063

Kabir, K., Khan, A., and Mosaddik, M. (2003). Goniothalamin-a potent mosquito larvicide from Bryonopsis laciniosa L. J Appl. Entomol 127, 112-115. doi: 10. 1046/j.1439-0418.2003.00716.x

Kalaivani, K., Senthil-Nathan, S., and Murugesan, A. G. (2012). Biological activity of selected Lamiaceae and Zingiberaceae plant essential oils against the dengue vector Aedes aegypti L. (Diptera: Culicidae). Parasitol. Res. 110, 1261-1268. doi: 10.1007/s00436-011-2623-x

Kamala-Jayanthi, P. D., Aurade, R. M., Kempraj, V., Chakravarthy, A. K., and Verghese, A. (2015). "Glimpses of semiochemical research applications in Indian horticulture: present status and future perspectives," in New Horizons 
in Insect Science: Towards Sustainable Pest Management, ed. A. Chakravarthy, (New Delhi: Springer), 239-257. doi: 10.1007/978-81-322-2089-3_22

Kamaraj, C., Deepak, P., Balasubramani, G., Karthi, S., Arul, D., Aiswarya, D., et al. (2018). Target and non-target toxicity of fern extracts against mosquito vectors and beneficial aquatic organisms. Ecotoxicol. Environ. Saf. 161, 221-230. doi: 10.1016/j.ecoenv.2018.05.062

Kannathasan, K., Senthilkumar, A., and Venkatesalu, V. (2011). Mosquito larvicidal activity of methyl-p-hydroxybenzoate isolated from the leaves of Vitex trifolia Linn. Acta Trop. 120, 115-118. doi: 10.1016/j.actatropica.2011. 07.001

Karunaratne, S. H. P. P., Jayawardena, K. G. I., Hemingway, J., and Ketterman, A. J. (1993). Characterisation of a B-type esterase involved in insecticide resistance from the mosquito Culex quinquefasciatus. Biochem. J. 294, 575-579. doi: 10.1042/bj2940575

Kaur, H., Arora, D. S., and Sharma, V. (2014). Isolation, purification and characterization of antimicrobial compound 6-[1, 2-dim.ethyl-6-(2-methylallyloxy)-hexyl]-3-(2-methoxy-phenyl)-chromen-4-one from Penicillium sp. HT 28. Appl. Biochem. Biotechnol. 173, 1963-1976. doi: 10.1007/s12010-0140979-Y

Kelm, M. A., Nair, M. G., and Schutzki, R. A. (1997). Mosquitocidal compounds from Magnolia salicifolia. Inter. J. Pharm. 35, 84-90. doi: 10.1076/phbi.35.2.84. 13279

Kim, S. I., and Ahn, Y.-J. (2017). Larvicidal activity of lignans and alkaloid identified in Zanthoxylum piperitum bark toward insecticide-susceptible and wild Culex pipiens pallens and Aedes aegypti. Parasit. Vectors 10:221. doi: 10. 1186/s13071-017-2154-0

Kimbaris, A. C., Koliopoulos, G., Michaelakis, A., and Konstantopoulou, M. A. (2012). Bioactivity of Dianthus caryophyllus, Lepidium sativum, Pimpinella anisum, and Illicium verum essential oils and their major components against the West Nile vector Culex pipiens. Parasitol. Res. 111, 2403-2410. doi: 10.1007/ s00436-012-3097-1

Kiran, S. R., Bhavani, K., Devi, P. S., Rao, B. R., and Reddy, K. J. (2006). Composition and larvicidal activity of leaves and stem essential oils of Chloroxylon swietenia DC against Aedes aegypti and Anopheles stephensi. Bioresour. Technol. 97, 2481-2484. doi: 10.1016/j.biortech.2005.10.003

Koodalingam, A., Deepalakshmi, R., Ammu, M., and Rajalakshmi, A. (2014). Effects of neemazal on marker enzymes and hemocyte phagocytic activity of larvae and pupae of the vector mosquito Aedes aegypti. J. Asia Pac. Entomol. 17, 175-181. doi: 10.1016/j.aspen.2013.12.007

Koutsaviti, K., Giatropoulos, A., Pitarokili, D., Papachristos, D., Michaelakis, A., and Tzakou, O. (2015). Greek Pinus essential oils: larvicidal activity and repellency against Aedes albopictus (Diptera: Culicidae). Parasitol. Res. 114, 583-592. doi: 10.1007/s00436-014-4220-2

Kulkarni, R. R., Pawar, P. V., Joseph, M. P., Akulwad, A. K., Sen, A., and Joshi, S. P. (2013). Lavandula gibsoni and Plectranthus mollis essential oils: chemical analysis and insect control activities against Aedes aegypti, Anopheles sfttephensi and Culex quinquefasciatus. J. Pestic. Sci. 86, 713-718. doi: 10.1007/s10340-0130502-1

Kuo, P. M., Chu, F. H., Chang, S. T., Hsiao, W. F., and Wang, S. Y. (2007). Insecticidal activity of essential oil from Chamaecyparis formosensis matsum. Holzforschung 61, 595-599. doi: 10.1515/HF.2007.087

Larson, M. J., Baldwin, S. A., Good, D. A., and Fair, J. E. (2010). Temporal stability of the error-related negativity (ERN) and post-error positivity $(\mathrm{Pe})$ : the role of number of trials. Psychophysiology 47, 1167-1171. doi: 10.1111/j.1469-8986. 2010.01022.x

Lee, J., Iwai, T., Yokota, T., and Yamashita, M. (2003). Temporally and spatially selective loss of Rec8 protein from meiotic chromosomes during mammalian meiosis. J. Cell Sci. 116, 2781-2790. doi: 10.1242/jcs.00495

Lee, S. E. (2000). Mosquito larvicidal activity of pipernonaline, a piperidine alkaloid derived from long pepper Piper longum. J. Am.Mosq. Control Assoc. $16,245-247$.

Leyva, M., Del Carmen Marquetti, M., Tacoronte, J. E., Scull, R., Tiomno, O., Mesa, A., et al. (2009b). Larvicidal activity of plant essential oils Aedes aegypti (L.) (Diptera: Culicidae). Rev. Bioméd. 20, 5-13.

Leyva, M., Marquetti, M. C., Tacoronte, J. E., Scull, R., Tiomno, O., Mesa, A., et al. (2009a). Actividad larvicida de aceites esenciales de plantas contra Aedes aegypti (L.) (Diptera: Culicidae). Rev. Biomed. 20, 5-13. doi: 10.32776/revbiomed.v20i1. 529
Leyva, M., Tacoronte, J. E., Marquetti, M. D. C., Scull, R., Montada, D., Rodríguez, Y., et al. (2008). Actividad insecticida de aceites esenciales de plantas en larvas de Aedes aegypti (Diptera: Culicidae). Rev. Cubana Med. Trop. 60, $78-82$.

Lija-Escaline, J., Senthil-Nathan, S., Thanigaivel, A., Pradeepa, V., VasanthaSrinivasan, P., Ponsankar, A., et al. (2015). Physiological and biochemical effects of botanical extract from Piper nigrum Linn (Piperaceae) against the dengue vector Aedes aegypti Liston (Diptera: Culicidae). Parasitol. Res. 114, 4239-4249. doi: 10.1007/s00436-015-4662-4661

Lima, M. A., De Oliveira, F. F. M., Gomes, G. A., Lavor, P. L., Santiago, G. M., Nagao-Dias, A. T., et al. (2011). Evaluation of larvicidal activity of the essential oils of plants species from Brazil against Aedes aegypti (Diptera: Culicidae). Afr. J. Biotechnol. 10:11716.

Lima-Santos, L., Barreto Brandão, L., Lopes Martins, R., de Menezes Rabelo, E., Lobato Rodrigues, A. B., da Conceição Vieira Araújo, C. M., et al. (2019). Evaluation of the larvicidal potential of the essential oil Pogostemon cablin (Blanco) Benth in the control of Aedes aegypti. Pharmaceuticals 12:53. doi: $10.3390 /$ ph12020053

Liu, X. C., Liu, Q., Zhou, L., and Liu, Z. L. (2014a). Evaluation of larvicidal activity of the essential oil of Allium macrostemon Bunge and its selected major constituent compounds against Aedes albopictus (Diptera: Culicidae). Parasit. Vectors 7:1. doi: 10.1186/1756-3305-7-184

Liu, X. C., Liu, Q. Y., Zhou, L., Liu, Q. R., and Liu, Z. L. (2014b). Chemical composition of Zanthoxylum avicennae essential oil and its larvicidal activity on Aedes albopictus Skuse. Trop. J. Pharm. Res. 13, 399-404.

Lounibos, L. P. (2002). Invasions by insect vectors of human disease. Ann. Rev. Entomol. 47, 33-66. doi: 10.1146/annurev.ento.47.091201.145206

Lucia, A., Audino, P. G., Seccacini, E., Licastro, S., Zerba, E., and Masuh, H. (2007). Larvicidal effect of Eucalyptus grandis essential oil and turpentine and their major components on Aedes aegypti larvae. J. Am. Mosq. Control Assoc. 23, 299-304. doi: 10.2987/8756-971X200723

Lucia, A., Juan, L. W., Zerba, E. N., Harrand, L., Marcó, M., and Masuh, H. M. (2012). Validation of models to estimate the fumigant and larvicidal activity of Eucalyptus essential oils against Aedes aegypti (Diptera: Culicidae). Parasitol. Res. 110, 1675-1686. doi: 10.1007/s00436-011-2685-9

Lucia, A., Licastro, S., Zerba, E., and Masuh, H. (2008). Yield, chemical composition, and bioactivity of essential oils from 12 species of Eucalyptus on Aedes aegypti larvae. Entomol. Exp. Appl. 129, 107-114. doi: 10.1111/j.15707458.2008.00757.x

Magalhães, A. M. L., da Paz Lima, M., Marques, O. M. M., Facanali, R., Pinto, A. C. D. S., and Pedro, T. W. (2010). Chemical composition and larvicidal activity against Aedes aegypti larvae of essential oils from four Guarea species. Molecules 15, 5734-5741. doi: 10.3390/molecules 15085734

Mansour, S., Messeha, S., and El-Gengaihi, S. (2000). Botanical biocides. 4. Mosquitocidal activity of certain Thymus capitatus constituents. J. Nat. Toxins $9,49-62$.

Mar, J. M., Silva, L. S., Azevedo, S. G., França, L. P., Goes, A. F., dos Santos, A. L., et al. (2018). Lippia origanoides essential oil: an efficient alternative to control Aedes aegypti, Tetranychus urticae and Cerataphis lataniae. Ind. Crops Prod. 111, 292-297. doi: 10.1016/j.indcrop.2017.10.033

Maradufu, A., Lubega, R., and Dorn, F. (1978). Isolation of (5E)-Ocimerone, a mosquito larvicide from Tagetes minuta. Lloydia 41, 181-183.

Marques, M. M., Morais, S. M., Vieira, I. G., Vieira, M. G., Silva, A. R. A., De Almeida, R. R., et al. (2011). Larvicidal activity of tagetes erecta against Aedes aegypti. J. Am. Mosq. Control Assoc. 27, 156-158. doi: 10.2987/106056.1

Massebo, F., Tadesse, M., Bekele, T., Balkew, M., and Gebre-Michael, T. (2009). Evaluation on larvicidal effects of essential oils of some local plants against anopheles arabiensis Patton and Aedes aegypti linnaeus (Diptera, Culicidae) in ethiopia. Afr. J. Biotechnol. 8, 4183-4188.

Massoud, R., Askov, K., Reinke, J., Franco, L. M., Bornstein, T., Knebel, E., et al. (2001). A Modern Paradigm for Improving Healthcare Quality. Quality Assurance Monograph. Available at: http:// www.qaproject.org (accessed March 19, 2019).

Michaelakis, A., Papachristos, D., Kimbaris, A., Koliopoulos, G., Giatropoulos, A., and Polissiou, M. G. (2009). Citrus essential oils and four enantiomeric pinenes against Culex pipiens (Diptera: Culicidae). Parasitol. Res. 105:769. doi: 10.1007/s00436-009-1452-7 
Moon, H.-I. (2011). Larvicidal activity of major essential oils from stems of Allium monanthum maxim. against Aedes aegypti L. J. Enzyme Inhib. Med. Chem. 26, 827-830. doi: 10.3109/14756366.2011.558842

Morais, S. M., Cavalcanti, E. S., Bertini, L. M., Oliveira, C. L. L., Rodrigues, J. R. B., and Cardoso, J. H. L. (2006). Larvicidal activity of essential oils from Brazilian Croton species against Aedes aegypti L. J. Am. Mosq. Control Assoc. 22, 161-165. doi: 10.2987/8756-971X200622

Mozaffari, E., Abai, M. R., Khanavi, M., Vatandoost, H., Sedaghat, M. M., Moridnia, A., et al. (2014). Chemical composition, larvicidal and repellency properties of Cionura erecta (L.) griseb. Against malaria vector, Anopheles stephensi Liston (Diptera: Culicidae). J. Arthr. Dis. 8:147.

Muema, J. M., Bargul, J. L., Njeru, S. N., Onyango, J. O., and Imbahale, S. S. (2017). Prospects for malaria control through manipulation of mosquito larval habitats and olfactory-mediated behavioural responses using plant-derived compounds. Parasit. Vectors. 10:184. doi: 10.1186/s13071-017-2122-8

Muleya, V., Hayeshi, R., Ranson, H., Abegaz, B., Bezabih, M. T., Robert, M., et al. (2008). Modulation of Anopheles gambiae epsilon glutathione transferase activity by plant natural products in vitro. J. Enzyme Inhib. Med. Chem. 23, 391-399. doi: 10.1080/14756360701546595

Mulla, M. S., and Su, T. (1999). Activity and biological effects of neem products against arthropods of medical and veterinary importance. J. Am. Mosq. Control Assoc. 15, 133-152.

Munda, S., Saikia, P., and Lal, M. (2018). Chemical composition and biological activity of essential oil of Kaempferia galanga: a review. J. Essen. Oil Res. 30, 303-308. doi: 10.1080/10412905.2018.1486240

Murugan, K., Jaganathan, A., Rajaganesh, R., Suresh, U., Madhavan, J., Senthil-Nathan, S., et al. (2018a). Poly (styrene sulfonate)/poly (allylamine hydrochloride) encapsulation of $\mathrm{TiO} 2$ nanoparticles boosts their toxic and repellent activity against zika virus mosquito vectors. J. Cluster Sci. 29, 27-39. doi: 10.1007/s10876-017-1300-3

Murugan, K., Roni, M., Panneerselvam, C., Suresh, U., Rajaganesh, R., Aruliah, R., et al. (2018b). Sargassum wightii-synthesized $\mathrm{ZnO}$ nanoparticles reduce the fitness and reproduction of the malaria vector Anopheles stephensi and cotton bollworm Helicoverpa armigera. Physiol. Mol. Plant Pathol. 101, 202-213. doi: 10.1016/j.pmpp.2017.02.004

Mwangi, J., Addae-Mensah, I., Muriuki, G., Munavu, R., Lwande, W. A., and Hassanali, A. (1992). Essential oils of lippia species in Kenya. IV: Maize weevil (Sitophilus zeamais) repellancy and larvicidal activity. Inter. J. Pharm. 30, 9-16. doi: 10.3109/13880209209054622

Nagella, P., Ahmad, A., Kim, S.-J., and Chung, I.-M. (2012). Chemical composition, antioxidant activity and larvicidal effects of essential oil from leaves of Apium graveolens. Immunopharmacol. Immunotoxicol. 34, 205-209. doi: 10.3109/ 08923973.2011.592534

Napoleão, T. H., Pontual, E. V., Lima, T. A., Santos, N. D. L., Sá, R. A., Coelho, L. C. B. B., et al. (2012). Effect of Myracrodruon urundeuva leaf lectin on survival and digestive enzymes of Aedes aegypti larvae. Parasitol. Res. 110, 609-616. doi: 10.1007/s00436-011-2529-7

Naqvi, S. (1987). "Biological evaluation of fresh neem extracts and some neem components, with reference to abnormalities and esterase activity in insects," in Proceedings of the First International Neem Conference, (Nairobi), 315-330.

Ndung'u, M., Hassanali, A., Hooper, A. M., Chhabra, S., Miller, T. A., Paul, R. L., et al. (2003). Ring A-seco mosquito larvicidal limonoids from turraea wakefieldii. Phytochemistry 64, 817-823. doi: 10.1016/j.phytochem.2003.08.020

Ndung'u, M. W., Kaoneka, B., Hassanali, A., Lwande, W., Hooper, A. M., Tayman, F., et al. (2004). New mosquito larvicidal tetranortriterpenoids from Turraea wakefieldii and Turraea floribunda. J. Agric. Food Chem. 52, 5027-5031. doi: 10.1021/jf049474y

Neira-Oviedo, M., Vanekeris, L., Corena-Mcleod, M. D. P., and Linser, P. J. (2008). A microarray-based analysis of transcriptional compartmentalization in the alimentary canal of Anopheles gambiae (Diptera: Culicidae) larvae. Insect Mol. Biol. 17, 61-72. doi: 10.1111/j.1365-2583.2008. 00779.x

Nikkon, F., Salam, K. A., Yeasmin, T., Mosaddik, A., Khondkar, P., and Haque, M. E. (2010). Mosquitocidal triterpenes from the stem of Duranta repens. Pharm. Biol. 48, 264-268. doi: 10.3109/13880200903096570

Niroumand, M. C., Heydarpour, F., and Farzaei, M. H. (2018). Pharmacological and therapeutic effects of Vitex agnus-castus L.: A review. Pharm. Rev. 12:103. doi: 10.4103/phrev.phrev_22_17

Nivsarkar, M., Kumar, G.-P., Laloraya, M., and Laloraya, M.-M. (1991). Superoxide dismutase in the anal gills of the mosquito larvae of Aedes aegypti: its inhibition by alpha-terthienyl. Arch. Insect. Biochem. Physiol. 4, 249-255. doi: 10.1002/ arch.940160404

Nyahanga, T., Jondika, J. I., Manguro, L. O. A., and Orwa, J. A. (2010). Chemical composition, antiplasmodial, larvicidal and antimicrobial activities of essential oils of Toddalia asiatica leaves and fruits. Int. J. Essen. Oil Ther. 4, 54-58.

Pandey, S., Upadhyay, S., and Tripathi, A. (2009). Insecticidal and repellent activities of thymol from the essential oil of Trachyspermum ammi (Linn) sprague seeds against Anopheles stephensi. Parasitol. Res. 105, 507-512. doi: 10.1007/s00436-009-1429-6

Park, H.-M., Kim, J., Chang, K.-S., Kim, B.-S., Yang, Y.-J., Kim, G.-H., et al. (2011). Larvicidal activity of Myrtaceae essential oils and their components against Aedes aegypti, acute toxicity on Daphnia magna, and aqueous residue. J. Med. Entomol. 48, 405-410. doi: 10.1603/ME10108

Patrakar, R., Mansuriya, M., and Patil, P. (2012). Phytochemical and pharmacological review on Laurus nobilis. Inter. J. Pharm. Chem. Sci. 1, 595-602.

Pavela, R. (2009). Larvicidal property of essential oils against Culex quinquefasciatus Say (Diptera: Culicidae). Indust. Crop. Prod. 30, 311-315. doi: 10.1016/j.indcrop.2009.06.005

Pavela, R. (2015). Essential oils for the development of eco-friendly mosquito larvicides: a review. Ind. Crops Prod. 76, 174-187. doi: 10.1016/j.indcrop.2015. 06.050

Pavela, R., and Govindarajan, M. (2017). The essential oil from Zanthoxylum monophyllum a potential mosquito larvicide with low toxicity to the non-target fish Gambusia affinis. J. Pest Sci. 90, 369-378. doi: 10.1007/s10340-016-0763-6

Pavela, R., Kaffkova, K., and Kumsta, M. (2014). Chemical composition and larvicidal activity of essential oils from different Mentha L. and Pulegium species against Culex quinquefasciatus say (Diptera: Culicidae). Plant Prot. Sci. 50, 36-41. doi: 10.17221/48/2013-PPS

Pereira, A. I. S., Pereira, A. D. G. S., Sobrinho, L., Palma, O., Cantanhede, E. D. K. P., and Siqueira, L. F. S. (2014). Antimicrobial activity in fighting mosquito larvae Aedes aegypti: homogenization of essential oils of linalool and eugenol. Educ. Quim. 25, 446-449.

Perumalsamy, H., Kim, N. J., and Ahn, Y. J. (2009). Larvicidal activity of compounds isolated from asarum heterotropoides against Culex pipiens pallens, Aedes aegypti, and Ochlerotatus togoi (Diptera: Culicidae). J. Med. Entomol. 46, 1420-1423. doi: 10.1603/033.046.0624

Pitarokili, D., Michaelakis, A., Koliopoulos, G., Giatropoulos, A., and Tzakou, O. (2011). Chemical composition, larvicidal evaluation, and adult repellency of endemic greek thymus essential oils against the mosquito vector of West Nile virus. Parasitol. Res. 109, 425-430. doi: 10.1007/s00436-011-2271-1

Pitasawat, B., Champakaew, D., Choochote, W., Jitpakdi, A., Chaithong, U., Kanjanapothi, D., et al. (2007). Aromatic plant-derived essential oil: an alternative larvicide for mosquito control. Fitoterapia 78, 205-210. doi: 10.1016/ j.fitote.2007.01.003

Pohlit, A. M., Lopes, N. P., Gama, R. A., Tadei, W. P., and De Andrade Neto, V. F. (2011). Patent literature on mosquito repellent inventions which contain plant essential oils - a review. Planta Med. 77, 598-617. doi: 10.1055/s-0030-127 0723

Pour, H. T., Shayeghi, M., Vat, H., and Abai, M. R. (2016). Study on larvicidal effects of essential oils of three Iranian native plants against larvae Anopheles stephensi (Liston). Vector Biol. J. 1:2.

Pradeepa, V., Sathish-Narayanan, S., Kirubakaran, S. A., and Senthil-Nathan, S. (2014). Antimalarial efficacy of dynamic compound of plumbagin chemical constituent from Plumbago zeylanica Linn (Plumbaginaceae) against the malarial vector Anopheles stephensi Liston (Diptera: Culicidae). Parasitol. Res. 113, 3105-3109. doi: 10.1007/s00436-014-4015-5

Pradeepa, V., Sathish-Narayanan, S., Kirubakaran, S. A., Thanigaivel, A., and Senthil-Nathan, S. (2015). Toxicity of aristolochic acids isolated from Aristolochia indica Linn (Aristolochiaceae) against the malarial vector Anopheles stephensi liston (Diptera: Culicidae). Exper. Parasitol. 153, 8-16. doi: 10.1016/j.exppara.2015.01.017

Pradeepa, V., Senthil-Nathan, S., Sathish-Narayanan, S., Selin-Rani, S., VasanthaSrinivasan, P., Thanigaivel, A., et al. (2016). Potential mode of action of a novel plumbagin as a mosquito repellent against the malarial vector Anopheles stephensi (Culicidae: Diptera). Pestic. Biochem.Physiol. 134, 84-93. doi: 10.1016/ j.pestbp.2016.04.001

Rahuman, A. A., Gopalakrishnan, G., Ghouse, B. S., Arumugam, S., and Himalayan, B. (2000). Effect of Feronia limonia on mosquito larvae. Fitoterapia 71, 553-555. doi: 10.1016/S0367-326X(00)00164-7 
Rahuman, A. A., Gopalakrishnan, G., Venkatesan, P., and Geetha, K. (2008a). Isolation and identification of mosquito larvicidal compound from Abutilon indicum (Linn.) Sweet. Parasitol. Res. 102, 981-988. doi: 10.1007/s00436-0070864-5

Rahuman, A. A., Gopalakrishnan, G., Venkatesan, P., Geetha, K., and Bagavan, A. (2008b). Mosquito larvicidal activity of isolated compounds from the rhizome of Zingiber officinale. Phytoth. Res. 22, 1035-1039. doi: 10.1002/ptr. 2423

Rattan, R. S. (2010). Mechanism of action of insecticidal secondary metabolites of plant origin. Crop Prot. 29, 913-920. doi: 10.1016/j.cropro.2010.05.008

Rey, D., Long, A., Pautou, M. P., and Meyran, J. C. (1999). Histopathological effects of tannic acid on the midgut epithelium of some aquatic diptera larvae. J. Invert. Pathol. 73, 173-181. doi: 10.1006/jipa.1998.4810

Rocha, D. K., Matos, O., Novo, M. T., Figueiredo, A. C., Delgado, M., and Moiteiro, C. (2015). Larvicidal activity against Aedes aegypti of Foeniculum vulgare essential oils from Portugal and Cape Verde. Nat. Prod. Commun. 4, 677-682. doi: 10.1177/1934578X1501000438

Rodrigues, A. M. S., De Paula, J. E., Roblot, F., Fournet, A., and Espíndola, L. S. (2005). Larvicidal activity of Cybistax antisyphilitica against Aedes aegypti larvae. Fitoterapia 76, 755-757. doi: 10.1016/j.fitote.2005.08.015

Rudin, W., and Hecker, H. (1989). Lectin binding sites in the midgut of the mosquitoes Anopheles stephensi liston and Aedes aegypti L. (Diptera, Culicidae). Parasitol. Res. 75, 268-279. doi: 10.1007/bf00931811

Ruiz, C., Cachay, M., Domínguez, M., Velásquez, C., Espinoza, G., Ventosilla, P., et al. (2011). Chemical composition, antioxidant and mosquito larvicidal activities of essential oils from Tagetes filifolia, Tagetes minuta and Tagetes elliptica from Perú. Planta Med. 77:E30. doi: 10.1055/s-0031-1282361

Saeed, M., Muhammad, N., and Khan, H. (2010). Analysis of toxic heavy metals in branded pakistani herbal products. J. Chem. Soc. Pak. 32:471.

Sakhanokho, H. F., Sampson, B. J., Tabanca, N., Wedge, D. E., Demirci, B., Baser, K. H. C., et al. (2013). Chemical composition, antifungal and insecticidal activities of Hedychium essential oils. Molecules 18, 4308-4327. doi: 10.3390/ molecules 18044308

Santiago, G. M., Lemos, T. L., Pessoa, O. D., Arriaga, A. M., Matos, F. J., Lima, M. A. S., et al. (2006). Larvicidal activity against Aedes aegypti L. (Diptera: Culicidae) of essential oils of Lippia species from Brazil. Nat. Prod. Commun. 1, 573-576. doi: 10.1177/1934578X0600100711

Santos, G. K., Dutra, K. A., Barros, R. A., da Câmara, C. A., Lira, D. D., Gusmão, N. B., et al. (2012). Essential oils from Alpinia purpurata (Zingiberaceae): chemical composition, oviposition deterrence, larvicidal and antibacterial activity. Ind. Crops Prod. 40, 254-260. doi: 10.1016/j.indcrop.2012.03.020

Santos, R. P., Nunes, E. P., Nascimento, R. F., Santiago, G. M. P., Menezes, G. H. A., Silveira, E. R., et al. (2006). Chemical composition and larvicidal activity of the essential oils of Cordia leucomalloides and Cordia curassavica from the Northeast of Brazil. J. Braz. Chem. Soci. 17, 1027-1030. doi: 10.1590/S010350532006000500030

Sedaghat, M. M., Dehkordi, A. S., Khanavi, M., Abai, M. R., Mohtarami, F., and Vatandoost, H. (2011). Chemical composition and larvicidal activity of essential oil of Cupressus arizonica EL Greene against malaria vector Anopheles stephensi liston (Diptera: Culicidae). Pharmacogn. Res. 3:135. doi: 10.4103/0974-8490. 81962

Selin-Rani, S., Senthil-Nathan, S., Thanigaivel, A., Vasantha-Srinivasan, P., Edwin, E. S., Ponsankar, A., et al. (2016). Toxicity and physiological effect of quercetin on generalist herbivore, Spodoptera litura Fab. and a non-target earthworm Eisenia fetida savigny. Chemosphere 165, 257-267. doi: 10.1016/j.chemosphere. 2016.08.136

Senthilkumar, A., Jayaraman, M., and Venkatesalu, V. (2013). Chemical constituents and larvicidal potential of Feronia limonia leaf essential oil against Anopheles stephensi, Aedes aegypti and Culex quinquefasciatus. Parasitol. Res. 112, 1337-1342. doi: 10.1007/s00436-012-3188-z

Senthilkumar, A., Kannathasan, K., and Venkatesalu, V. (2008). Chemical constituents and larvicidal property of the essential oil of Blumea mollis (D. Don) Merr. against Culex quinquefasciatus. Parasitol. Res. 103, 959-962. doi: 10.1007/s00436-008-1085-2

Senthil-Nathan, S. (2007). The use of eucalyptus leaf extract as a natural larvicidal agent against malarial vector Anopheles stephensi Liston (Diptera: Culicidae). Bioresour. Technol. 98, 1856-1860. doi: 10.1016/j.biortech.2006.07.044
Senthil-Nathan, S. (2013). Physiological and biochemical effect of neem and other Meliaceae plants secondary metabolites against Lepidopteran insects. Front. Physiol. 4:359. doi: 10.3389/fphys.2013.00359

Senthil-Nathan, S. (2015). "A review of biopesticides and their mode of action against insect pests," in Environmental Sustainability, ed. G. Sridevi, (Berlin: Springer).

Senthil-Nathan, S., Choi, M. Y., Paik, C. H., Seo, H. Y., and Kalaivani, K. (2009). Toxicity and physiological effects of neem pesticides applied to rice on the Nilaparvata lugens Stål, the brown planthopper. Ecotoxicol. Environ. Saf. 72, 1707-1713. doi: 10.1016/j.ecoenv.2009.04.024

Senthil-Nathan, S., Hisham, A., and Jayakumar, G. (2008). Larvicidal and growth inhibition of the malaria vector Anopheles stephensi by triterpens from Dysoxylum spp. (Meliaceae). Fitoterapia 76, 106-111. doi: 10.1016/j.fitote.2007. 07.013

Senthil-Nathan, S., and Kalaivani, K. (2005). Efficacy of nucleopolyhedrovirus and azadirachtin on Spodoptera litura fabricius (Lepidoptera: Noctuidae). Biol. Control 34, 93-98. doi: 10.1016/j.biocontrol.2005.03.001

Senthil-Nathan, S., and Kalaivani, K. (2006). Combined effects of azadirachtin and nucleopolyhedrovirus (SpltNPV) on Spodoptera litura fabricius (Lepidoptera: Noctuidae) larvae. Biol. Control 39, 96-104. doi: 10.1016/j.biocontrol.2006. 06.013

Senthil-Nathan, S., Kalaivani, K., and Chung, P. G. (2005a). The effects of azadirachtin and nucleopolyhedrovirus on midgut enzymatic profile of Spodoptera litura Fab.(Lepidoptera: Noctuidae). Pestic. Bichem. Physiol. 83, 46-57. doi: 10.1016/j.pestbp.2005.03.009

Senthil-Nathan, S., Kalaivani, K., and Murugan, K. (2005b). Effects of neem limonoids on the malaria vector Anopheles stephensi liston (Diptera: Culicidae). Acta Trop. 96, 47-55. doi: 10.1016/j.actatropica.2005.07.002

Senthil-Nathan, S., Kalaivani, S., and Sehoon, K. (2006a). Effects of Dysoxylum malabaricum Bedd (Meliaceae) extract on the malarial vector Anopheles stephensi Liston (Diptera: Culicidae). Bioresour. Technol. 97, 2077-2083. doi: 10.1016/j.biortech.2005.09.034

Senthil-Nathan, S., Savitha, G., George, D. K., Narmadha, A., Suganya, L., and Chung, P. G. (2006b). Efficacy of Melia azedarach L. extract on the malarial vector Anopheles stephensi Liston. Bioresour. Technol. 97, 1214-1221. doi: 10. 1016/j.biortech.2005.05.019

Seo, S.-M., Jung, C.-S., Kang, J., Lee, H.-R., Kim, S.-W., Hyun, J., et al. (2015). Larvicidal and acetylcholinesterase inhibitory activities of Apiaceae plant essential oils and their constituents against Aedes albopictus and formulation development. J. Agric. Food Chem. 63, 9977-9986. doi: 10.1021/acs.jafc. $5 \mathrm{~b} 03586$

Service, M. W. (1996). Medical Entomology for Students. London: Chapman and Hall.

Shaalan, E., Canyon, D., Younes, M. W. F., Abdel-Wahab, H., and Mansour, A. (2005). A review of botanical phytochemicals with mosquitocidal potential. Environ. Int. 31, 1149-1166. doi: 10.1016/j.envint.2005.03.003

Shaalan, E. A. S., Canyon, D. V., Bowden, B., Younes, M. W. F., Abdel-Wahab, H., and Mansour, A. H. (2006). Efficacy of botanical extracts from Callitris glaucophylla against Aedes aegypti and Culex annulirostris mosquitoes. Trop. Biomed. 23, 180-185.

Shunying, Z., Yang, Y., Huaidong, Y., Yue, Y., and Guolin, Z. (2005). Chemical composition and antimicrobial activity of the essential oils of Chrysanthemum indicum. J. Ethnopharmacol. 96, 151-158. doi: 10.1016/j.jep.2004.08.031

Siddiqui, B. S., Afshan, F., Afshan, F., Ghiasuddin, S. F., Naqvi, S. N.-U.-H., Tariq, R. M., et al. (1999). New insect-growth-regulator meliacin butenolides from the leaves of Azadirachta indica A. Juss. J. Chem. Soci. Perkin Trans. 1, 2367-2370. doi: 10.1039/A902326G

Siddiqui, B. S., Afshan, F., Faizi, S., Naeem-Ul-Hassan Naqvi, S., and Tariq, R. M. (2002). Two new triterpenoids from Azadirachta indica and their insecticidal activity. J. Nat. Prod. 65, 1216-1218. doi: 10.1021/np0105477

Siddiqui, B. S., Afshan, F., Gulzar, T., Sultana, R., Naqvi, S. N.-H., and Tariq, R. M. (2003). Tetracyclic triterpenoids from the leaves of Azadirachta indica and their insecticidal activities. Chem. Pharm. Bull. 51, 415-417. doi: 10.1248/cpb.51.415

Sola, P., Mvumi, B. M., Ogendo, J. O., Mponda, O., Kamanula, J. F., Nyirenda, S., et al. (2014). Botanical pesticide production, trade and regulatory mechanisms in sub-Saharan Africa: making a case for plant-based pesticidal products. Food Secur. 6, 369-384. doi: 10.1007/s12571-014-0343-7 
Souza, L. G. D. S., Almeida, M. C. S., Monte, F. J. Q., Santiago, G. M. P., BrazFilho, R., Lemos, T. L. G., et al. (2012). Chemical constituents of Capraria biflora (Scrophulariaceae) and larvicidal activity of essential oil. Quím. Nova 35, 2258-2262. doi: 10.1590/S0100-40422012001100032

Stenfors Arnesen, L. P., Fagerlund, A., and Granum, P. E. (2008). From soil to gut: Bacillus cereus and its food poisoning toxins. FEMS Microbiol. Rev. 32, 579-606. doi: 10.1111/j.1574-6976.2008.00112.x

Sujatha, G., Kumari, R., and Bollipo, D. (2013). Composition and larvicidal activity of Artemisia vulgaris L. stem essential oil against Aedes aegypti. Jord. J. Biol. Sci. $147,1-5$.

Sukumar, K., Perich, M. J., and Boobar, L. R. (1991). Botanical derivatives in mosquito control: a review. J. Am. Mosq. Control Assoc. 7, 210-237.

Sun, R., Sacalis, J. N., Chin, C.-K., and Still, C. C. (2001). Bioactive aromatic compounds from leaves and stems of Vanilla fragrans. J. Agric. Food Chem. 49, 5161-5164. doi: 10.1021/jf010425k

Sutthanont, N., Choochote, W., Tuetun, B., Junkum, A., Jitpakdi, A., Chaithong, U., et al. (2010). Chemical composition and larvicidal activity of edible plantderived essential oils against the pyrethroid-susceptible and-resistant strains of Aedes aegypti (Diptera: Culicidae). J. Vector Ecol. 35, 106-115. doi: 10.1111/j. 1948-7134.2010.00066.x

Syed, Z., and Leal, W. S. (2008). Mosquitoes smell and avoid the insect repellent DEET. Proc. Nat. Acad. Sci. U.S.A. 105, 13598-13603. doi: 10.1073/pnas. 0805312105

Tabanca, N., Demirci, B., Kiyan, H. T., Ali, A., Bernier, U. R., Wedge, D. E., et al. (2012a). Repellent and larvicidal activity of Ruta graveolens essential oil and its major individual constituents against Aedes aegypti. Planta Med. 78:90. doi: 10.1055/s-0032-1307598

Tabanca, N., Özek, G., Ali, A., Duran, A., Hamzaoð̋lu, E., Başer, K. H. C., et al. (2012b). Chemical composition of Heracleum pastinacifolium subsp. transcaucasicum and subsp. incanum essential oils, and their biting deterrent and larvicidal activity against Aedes aegypti. Planta Med. 78:89. doi: 10.1055/s0032-1307597

Tehri, K., and Singh, N. (2015). The role of botanicals as green pesticides in integrated mosquito management-A review. Inter. J. Mosq. Res. 2, $18-23$.

Thanigaivel, A., Chandrasekaran, R., Revathi, K., Nisha, S., Sathish-Narayanan, S., Kirubakaran, S. A., et al. (2012). Larvicidal efficacy of Adhatoda vasica (L.) Nees against the bancroftian filariasis vector Culex quinquefasciatus Say and dengue vector Aedes aegypti L. in in vitro condition. Parasitol. Res. 110, 1993-1999. doi: 10.1007/s00436-011-2728-2

Thanigaivel, A., Chanthini, K. M. P., Karthi, S., Vasantha-Srinivasan, P., Ponsankar, A., Sivanesh, H., et al. (2019). Toxic effect of essential oil and its compounds isolated from Sphaeranthus amaranthoides Burm. f. against dengue mosquito vector Aedes aegypti Linn. Pestic. Bichem. Physiol. 160, 163-170. doi: 10.1016/j. pestbp.2019.08.006

Thanigaivel, A., Senthil-Nathan, S., Vasantha-Srinivasan, P., Edwin, E. S., Ponsankar, A., Selin-Rani, S., et al. (2017a). Chemicals isolated from Justicia adhatoda Linn reduce fitness of the mosquito, Aedes aegypti L. Arch. Insect Biochem. Physiol. 94:e21384. doi: 10.1002/arch.21384

Thanigaivel, A., Vasantha-Srinivasan, P., Edwin, E.-S., Ponsankar, A., Selin-Rani, S., Chellappandian, M., et al. (2017b). Development of an eco-friendly mosquitocidal agent from Alangium salvifolium against the dengue vector Aedes aegypti and its biosafety on the aquatic predator. Environ. Sci. Pollut. Res. 25, 10340-10352. doi: 10.1007/s11356-0179102-6

Tiwary, M., Naik, S. N., Tewary, D. K., Mittal, P. K., and Yadav, S. (2007). Chemical composition and larvicidal activities of the essential oil of Zanthoxylum armatum DC (Rutaceae) against three mosquito vectors. J. Vector Born. Dis. 44:198.

Torres, M. C. M., Assunção, J. C., Santiago, G. M. P., Andrade-Neto, M., Silveira, E. R., Costa-Lotufo, L. V., et al. (2008). Larvicidal and nematicidal activities of the leaf essential oil of croton regelianus. Chem. Biodivers. 5, 2724-2728. doi: 10.1002/cbdv.200890227

Traboulsi, A. F., Taoubi, K., El-Haj, S., Bessiere, J. M., and Rammal, S. (2002). Insecticidal properties of essential plant oils against the mosquito Culex pipiens molestus (Diptera: Culicidae). Pestic. Manag. Sci. 58, 491-495. doi: 10.1002/ps. 486

Trindade, F. T. T., Stabeli, R. G., Pereira, A. A., Facundo, V. A., and de Almeida, A. (2013). Copaifera multijuga ethanolic extracts, oilresin, and its derivatives display larvicidal activity against Anopheles darlingi and Aedes aegypti (Diptera: Culicidae). Rev. Bras. Farmacogn. 23, 464-470. doi: 10.1590/ S0102-695X2013005000038

Tripathi, A. K., Upadhyay, S., Bhuiyan, M., and Bhattacharya, P. R. (2009). A review on prospects of essential oils as biopesticides in insect pest management. J. Pharmacogn. Phytother. 1, 52-63.

Tyagi, B. K., Munirathinam, A., and Venkatesh, A. (2015). A catalogue of indian mosquitoes. Inter. J. Mosq. Res. 2, 50-97. doi: 10.1186/s12864-018-4729-3

Urich, K. (1994). Comparative Animal Biochemistry. Berlin: Springer-Verlag.

Vasantha-Srinivasan, P., Karthi, S., Chellappandian, M., Ponsankar, A., Thanigaivel, A., Senthil-Nathan, S., et al. (2019). Aspergillus flavus (Link) toxins reduces the fitness of dengue vector Aedes aegypti (Linn.) and their non-target toxicity against aquatic predator. Microb. Pathog. 128, 281-287. doi: 10.1016/j.micpath.2019.01.014

Vasantha-Srinivasan, P., Senthil-Nathan, S., Ponsankar, A., Thanigaivel, A., Edwin, E. S., Selin-Rani, S., et al. (2017). Comparative analysis of mosquito (Diptera: Culicidae: Aedes aegypti Liston) responses to the insecticide Temephos and plant derived essential oil derived from Piper betle L. Ecotoxicol. Environ. Saf. 139, 439-446. doi: 10.1016/j.ecoenv.2017.01.026

Vasantha-Srinivasan, P., Thanigaivel, A., Edwin, E. S., Ponsankar, A., SenthilNathan, S., Selin-Rani, S., et al. (2018). Toxicological effects of chemical constituents from Piper against the environmental burden Aedes aegypti Liston and their impact on non-target toxicity evaluation against biomonitoring aquatic insects. Environ. Sci. Pollut. Res. 25, 10434-10446. doi: 10.1007/s11356017-9714-X

Velu, K., Elumalai, D., Hemalatha, P., Janaki, A., Babu, M., Hemavathi, M., et al. (2015). Evaluation of silver nanoparticles toxicity of Arachis hypogaea peel extracts and its larvicidal activity against malaria and dengue vectors. Environ. Sci. Poll. Res. 22, 17769-17779. doi: 10.1007/s11356-015-4919-3

Vera, S. S., Zambrano, D. F., Méndez-Sanchez, S. C., Rodríguez-Sanabria, F., Stashenko, E. E., and Luna, J. E. D. (2014). Essential oils with insecticidal activity against larvae of Aedes aegypti (Diptera: Culicidae). Parasitol. Res. 113, 2647-2654. doi: 10.1007/s00436-014-3917-6

Vivekanandhan, P., Senthil-Nathan, S., and Shivakumar, M. S. (2018a). Larvicidal, pupicidal and adult smoke toxic effects of Acanthospermum hispidum (DC) leaf crude extracts against mosquito vectors. Physiol. Mol. Plant Pathol. 101, 156-162. doi: 10.1016/j.pmpp.2017.05.005

Vivekanandhan, P., Venkatesan, R., Ramkumar, G., Karthi, S., Senthil-Nathan, S., and Shivakumar, M. S. (2018b). Comparative analysis of major mosquito vectors response to seed-derived essential oil and seed pod-derived extract from Acacia nilotica. Intern. J. Environ. Res. Public Health. 15:388. doi: 10.3390/ ijerph 15020388

Vourlioti-Arapi, F., Michaelakis, A., Evergetis, E., Koliopoulos, G., and Haroutounian, S. (2012). Essential oils of indigenous in Greece six Juniperus taxa. Parasitol. Res. 110, 1829-1839. doi: 10.1007/s00436-011-2706-8

Wahyuni, D. (2012). Larvicidal activity of essential oils of Piper betle from the Indonesian plants against Aedes aegypti L. J. Appl. Environ. Biol. Sci. 2, 249-254.

Walter, K., and Schütt, C. (1974). "Acid and alkaline phosphatase in serum (Two-point method)," in Methods of Enzymatic Analysis, ed. H. U. Bergmeyer, (Florida: Verlag Chemie GmbH), 856-860. doi: 10.1016/b978-0-12-091302-2. 50067-0

Wheelock, C. E., Shan, G., and Ottea, J. A. (2005). Overview of carboxylesterases and their role in metabolism of insecticides. J. Pestic. Sci. 30, 75-83. doi: 10. 1584/jpestics.30.75

World Health Organization [WHO] (2017). Annex 1. Global Burden of Major Vector-Borne Diseases, as of March 2017. Geneva: WHO.

Wu, L.-Y., Gao, H.-Z., Wang, X.-L., Ye, J.-H., Lu, J.-L., and Liang, Y.-R. (2010). Analysis of chemical composition of Chrysanthemum indicum flowers by GC/MS and HPLC. J. Med. Plants Res. 4, 421-426.

Yang, Y.-C., Lee, S.-G., Lee, H.-K., Kim, M.-K., Lee, S.-H., and Lee, H.-S. (2002). A piperidine amide extracted from Piper longum L. fruit shows activity against Aedes aegypti mosquito larvae. J. Agric. Food Chem. 50, 3765-3767. doi: 10. 1021/jf011708f

Yenesew, A., Derese, S., Midiwo, J. O., Heydenreich, M., and Peter, M. G. (2003). Effect of rotenoids from the seeds of Millettia dura on larvae of Aedes aegypti. Pestic. Manag. Sci. 59, 1159-1161. doi: 10.1002/ps.740

Yu, C. H., Dang, Y. K., Zhou, Z. P., Wu, C., Zhao, F. Z., Sachs, M. S., et al. (2015). Codon usage influences the local rate of translation elongation to regulate cotranslational protein folding. Mol. Cell 59, 744-754. doi: 10.1016/j.molcel.2015. 07.018 
Zhang, J., Huang, T., Zhang, J., Shi, Z., and He, Z. (2018). Chemical composition of leaf essential oils of four Cinnamomum species and their larvicidal activity against Anopheleus sinensis (Diptera: Culicidae). J. Essen. Oil Bear. Plants 21, 1284-1294. doi: 10.1080/0972060X.2018.1552205

Zhu, J., Zeng, X., Liu, T., Qian, K., Han, Y., Xue, S., et al. (2006). Adult repellency and larvicidal activity of five plant essential oils against mosquitoes. J. Am. Mosq. Control Assoc. 22, 515-522. doi: 10.2987/8756-971x(2006)22\\%5B515: aralao $\backslash \% 5 \mathrm{D} 2.0 . \mathrm{co} ; 2$

Zhu, L., and Tian, Y. (2011). Chemical composition and larvicidal activity of Blumea densiflora essential oils against Anopheles anthropophagus: a malarial vector mosquito. Parasitol. Res. 109, 1417-1422. doi: 10.1007/s00436-0112388- 2

Zibaee, A. (2011). "Botanical insecticides and their effects on insect biochemistry and immunity," in Pesticides in the Modern World - Pests Control and Pesticides Exposure and Toxicity Assessment, ed. M. Stoytcheva, (London: IntechOpen), doi: $10.5772 / 16550$
Zibaee, A., and Bandani, A. R. (2010). Effects of Artemisia annua L. (Asteracea) on digestive enzymes profiles and cellular immune reactions of sunn pest, Eurygaster integriceps (Heteroptera: Scutellaridae), against Beauvaria bassiana. Bull. Entomol. Res. 100, 185-196. doi: 10.1017/S00074853099 9014

Conflict of Interest: The author declares that the research was conducted in the absence of any commercial or financial relationships that could be construed as a potential conflict of interest.

Copyright $(2020$ Senthil-Nathan. This is an open-access article distributed under the terms of the Creative Commons Attribution License (CC BY). The use, distribution or reproduction in other forums is permitted, provided the original author(s) and the copyright owner(s) are credited and that the original publication in this journal is cited, in accordance with accepted academic practice. No use, distribution or reproduction is permitted which does not comply with these terms. 